RECONMAISSANCE STUDY OF STREAM SEDIMENTATION, SOUTHERN GUAM

By Patricia J. Shade

U.S. GEOLOGICAL SURVEY

Water-Resources Investigations Report 83-4212

Prepared in cooperation with the

U.S. DEPARTMENT OF THE ARMY

PACIFIC OCEAN DIVISION

CORPS OF ENGINEERS

FT. SHAFTER, HAWAII

Honolulu, Hawai i

December 1983 
UNITED STATES DEPARTMENT OF THE INTERIOR

JAMES G. WATT, Secretary

GEOLOGICAL SURVEY

Dallas L. Peck, Director

For additional information write to:

District Chief

U.S. Geological Survey, WRD

Rm. 6110, 300 Ala Moana Blvd.

Honolulu, Hawaii 96850
Copies of this report

can be purchased from:

Open-File Services Section

Western Distribution Branch

U.S. Geological Survey

Box 25425, Federal Center

Denver, Colorado 80225

(Telephone: [303] 234-5888) 


\section{CONTENTS}

Page

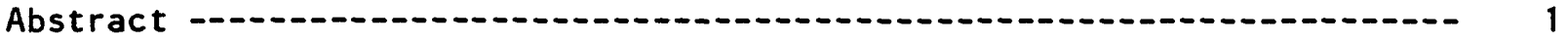

Introduction

Purpose and scope

Physiography

Calculation of sediment yield

Flow-duration sediment-rating-curve method

Pacific Southwest Inter-Agency Committee (PSIAC) method - 17 Comparison of results with Hawai ian data Conclusion

References 


\section{ILLUSTRATIONS}

Figure

1. Map showing location of Guam 3

2. Map showing gaging station locations in study area of the

I sland of Guam

3.-5. Graphs showing flow-duration curves for:

3. Station 16850000 , Talofofo River near Talofofo, Guam, October 1953 - September 1961 - 7

4. Station 16858000 , Ylig River near Yona, Guam, October 1953 - September 1980 - 8

5. Station 16854500 , Ugum River above Talofofo Falls, October 1978 - September 1981 - 9

6. Graph showing the instantaneous sediment rating curve for station 16850000, Talofofo River near Talof ofo, Guam -...- 10

7. Graph showing the daily sediment rating curve for station 16858000, Ylig River near Yona, Guam,

August 1980 - September 1981 - 11

8. Graph showing the daily sediment rating curve for station 16854500, Ugum River above Talofofo Falls, October 1980 - June 1981

9. Map showing location of Fena Reservoir drainage area

10. Map showing Talofofo and Fena Reservoir drainage areas _-_._._. 22

11. Map showing the geology of Fena Reservoir drainage area

12. Map showing the soils of Fena Reservoir drainage area

13. Map showing the vegetation of Fena Reservoir drainage area $\ldots \ldots$ 


\section{TABLES}

Table

1.-3. Estimation of mean annual sediment discharge for:

1. Talofofo River 14

2. Ylig River - 15

3. Ugum River - 16

4. Factors affecting sediment yield 18

5. PSIAC rating conversions 19

6. Sample computation of PSIAC value for Fena soils

7. PSIAC values for factors affecting sediment yield in

Fena Reservoir drainage area 28

8. PSIAC values for factors affecting sediment yield in

Talofofo, Ugum, and Ylig drainage areas 29

9. Computed annual sediment yields for streams on 0ahu 


\section{CONVERSION TABLE}

The following table may be used to convert measurements in the inch-pound system to the International System of Units (SI).

Multiply inch-pound units

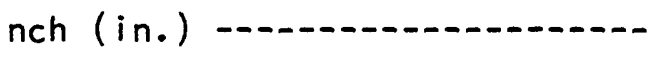

foot $(f t)$

mile (mi)

By

To obtain SI (metric) units

\section{Length}

$$
\begin{array}{lll}
25.4 & \cdots & \text { millimeter }(\mathrm{mm}) \\
0.3048 & \cdots & \text { meter }(\mathrm{m}) \\
1.609 & \cdots & \text { kilometer }(\mathrm{km})
\end{array}
$$

\section{Area}

acre

4,047

2.590

-.- square meter $\left(\mathrm{m}^{2}\right)$

square mile $\left(\mathrm{mi}^{2}\right)$

Volume

acre-foot (acre-ft)

cubic foot $\left(f t^{3}\right)$

1,233

33 cubic meter $\left(\mathrm{m}^{3}\right)$

$0.02832 \ldots$ cubic meter $\left(\mathrm{m}^{3}\right)$

\section{Volume Per Unit Time (includes Flow)}

cubic foot per second $\left(\mathrm{ft}^{3} / \mathrm{s}\right)$--

cubic foot per second-day

$$
\left(f t^{3} / s-d\right)
$$

2,447

-.- cubic meter $\left(\mathrm{m}^{3}\right)$

Weight Per Volume

pounds per cubic foot $\left(1 \mathrm{bs} / \mathrm{ft}^{3}\right)$ cubic meter per second $\left(\mathrm{m}^{3} / \mathrm{s}\right)$ ki lograms per cubic meter $\left(\mathrm{kg} / \mathrm{m}^{3}\right)$ 


\title{
RECONNAISSANCE STUDY OF STREAM SEDIMENTATION, SOUTHERN GUAM
}

\author{
By Patricia J. Shade
}

\section{ABSTRACT}

Sediment yields for three drainage basins in southern Guam were estimated by the flow-duration sediment-rating curve method, reservoir survey data, and the PSIAC (Pacific Southwest Inter-Agency Committee) formula.

Daily suspended-sediment samples were collected at U.S. Geological Survey gaging stations on the Ylig and Ugum Rivers from August 1980 to September 1981. Intermittent samples were collected from the Talofofo River between June and November of 1972. Although limited, these data are used with the flow-duration sediment-rating-curve method to estimate mean suspended-sediment yields. Fena Reservoir sedimentation data are used to test the applicability of the PSIAC formula in the three basins.

Estimates of suspended-sediment yield are 462 to 845 tons per year per square mile (tons/yr/mi ${ }^{2}$ ) for the Talofofo basin, 977 to 1,162 tons/yr/mi ${ }^{2}$ for the Ylig basin, and 855 to 1,455 tons $/ \mathrm{yr} / \mathrm{mi}^{2}$ for the Ugum basin. PSIAC est imates of total sediment yield are 1,200 tons $/ \mathrm{yr} / \mathrm{mi}^{2}$ for the Talofofo, 1,385 tons/yr $/ \mathrm{mi}^{2}$ for the $\mathrm{Ylig}$, and 1,210 tons/yr/mi ${ }^{2}$ for the Ugum basins. These values are comparable to estimates of sediment yields from several similar small basins on Oahu, Hawaii.

It appears from this study that the PSIAC method can be a useful tool in estimating sediment yields in some tropical areas. 


\section{INTRODUCTION}

\section{Purpose and Scope}

The Talofofo, Ylig, and Ugum River basins are located in southern Guam, where surface water is the major source of domestic water supply. The usefulness of the surface water supply largely depends on the water quality as well as the quantity as dictated by the climatic and hydrologic cycles. The purpose of this study is to determine the mean annual sediment yields from these three major river basins in the area, for use in future water supply development.

Suspended sediment data from the Talofofo, Ylig, and Ugum Rivers, are used with the flow-duration sediment-rating-curve method to estimate mean annual suspended-sediment yield for each of the three basins. Fena Reservoir sedimentation data are used to test the applicability of the PSIAC (Pacific Southwest Inter-Agency Committee, 1968) formula for estimating mean annual sediment yield in southern Guam. Estimates by the PSIAC formula for the Talofofo, Ylig, and Ugum basins are also compared with mean annual sediment yields for several similar basins on Oahu, Hawaii.

\section{Physiography}

Guam is the largest of the Mariana Islands, located about 1,370 miles southeast of Tokyo and about $1,500 \mathrm{miles}$ east of the Philippine Islands (fig. 1). The island is 30 miles long and about $8-1 / 2$ miles wide in the northern part, tapering to 4 miles at the central part, and increasing to 11-1/2 miles wide in the southern part. The axis of the northern part of the island trends northeast, and in the southern part, the trend is north-south (fig. 2).

The climate of Guam is warm and humid. The mean annual temperature is about $81^{\circ} \mathrm{F}$ with little variation about the mean throughout the year. There are two distinct seasons, a dry season from January through May, and a wet season from July through November. June and December are transitional months. The mean annual rainfall ranges from about 80 inches in the west-central coastal areas to about 100 inches in the highest mountain areas in southern Guam. About 15-20 percent of the total rainfall occurs during the dry season and about 70 percent during the wet season, with the remainder occurring during the transitional months. 


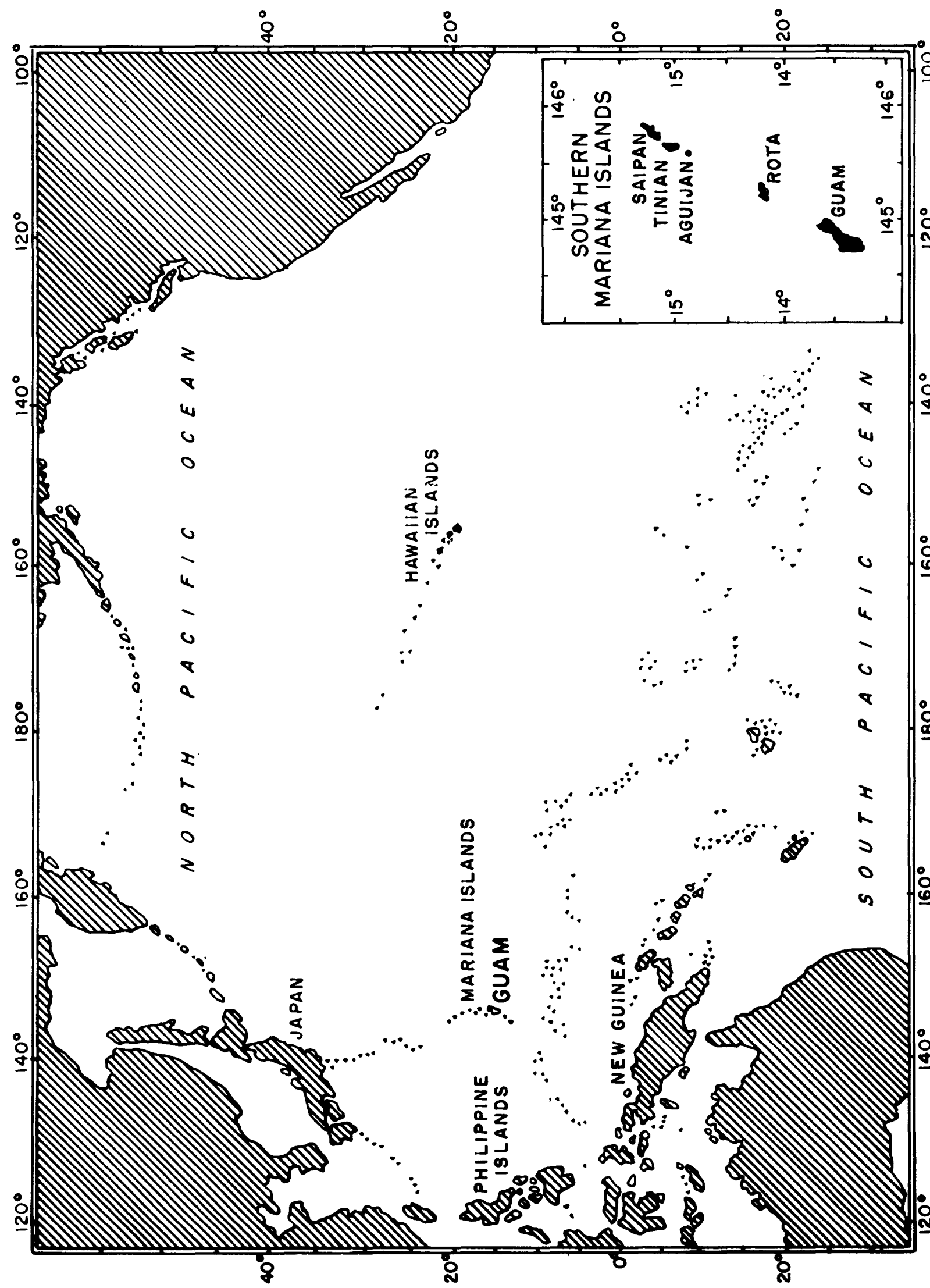

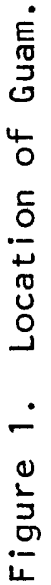




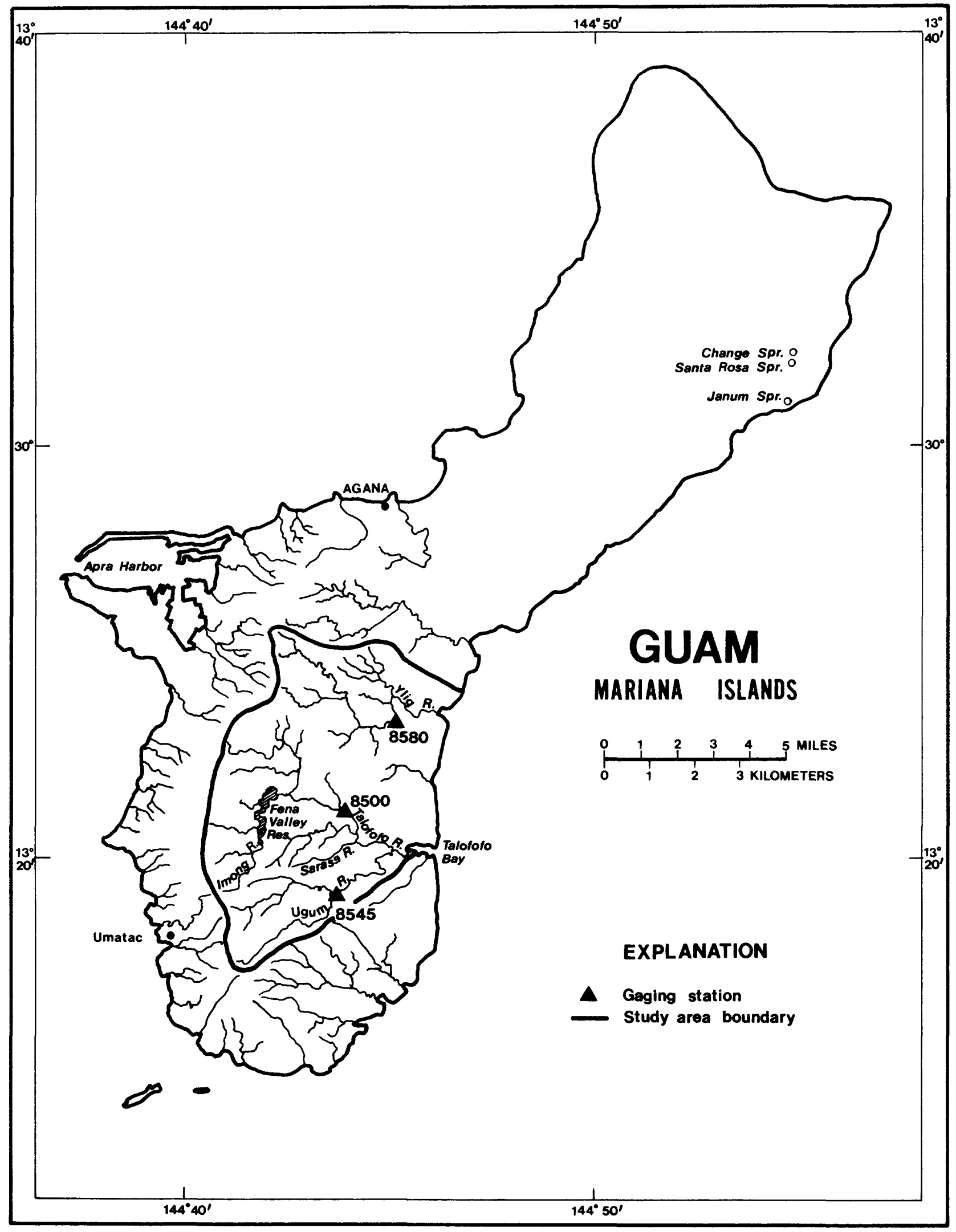

Figure 2. Gaging station locations in study area of the Island of Guam. 
Typhoons are fairly common during the wet season, dropping large amounts of rain in a few days. During the typhoon in 0ctober 1953, 26 inches of rain fell in one day and the 2-day total was 48 inches at Umatac, on the southwest coast. Drought, defined by Blumenstock (in Tracey and others, 1959) as any month with less than 4 inches of rain, is also common and may be expected to occur from February through April in 3 out of 4 years.

There are three broad physiographic areas: the northern limestone plateau; the central mountains; and the southern volcanic mountains. Virtually all the surface runoff occurs in the southern part of the island. In the Talofofo, Ylig, and Ugum River valleys in the south, the volcanic rocks are deeply weathered and have low permeabilities. The soils are predominantly clays.

The Ugum River joins the Talofofo River about 0.5 mile above Talofofo Bay. The basins are underlain generally by deeply weathered consolidated noncalcareous sedimentary rocks derived from volcanic rocks, except along the lower reaches of the streams where the valley flats are underlain by alluvium. In its steep upper basin, the Ylig River and its tributaries flow across deeply weathered volcanic rock. The valley flat is underlain by alluvium (fig. 2) (Ward and others, 1965).

Because of the generally low permeability of the rocks in these basins, about half the average daily rainfall runs off during the rainy season. At the end of the wet season, streamflow decreases rapidly to the low flow maintained by slow ground-water discharge (Ward and others, 1965).

The upland part of the study area is steep and dissected by numerous streams. Surface gradients range generally from 15 to 100 percent and decrease toward the east where the streams have more gentle gradients. Farming, grazing, and small settlements predominate in the eastern part of the study area and in the valley flats. A naval installation surrounds Fena Reservoir, and the remainder of the basin uplands is undeveloped. Vegetative cover on the uplands is largely swordgrass and scattered trees, with broad-leafed forests in the ravines and valleys (Tracey and others, 1959). 


\section{Flow-Duration Sediment-Rating-Curve Method}

Estimates of the mean annual suspended-sediment discharge from the Talofofo, Ylig, and Ugum drainage areas were made using the flow-duration sediment-rating-curve method (Miller, 1951). Flow-duration curves (figs. 3 to 5) were prepared for the rivers using the entire period of streamflow records available at Geological Survey gaging stations 16850000 on the Talofofo River (1953-61), 16858000 on the Ylig River (1953-80), and 16854500 on the Ugum River (1978-81) (For station locations, see fig. 2). A flow-duration curve is a cumulative frequency curve that shows the percentage of time within the total period of record that a specified daily discharge was equaled or exceeded. It combines, in one curve, the flow characteristics of a stream throughout the range of discharge without regard to the sequence of occurrence. Because the upper end of the flow-duration curve represents the flows that transport most of the sediment, the Talofofo and Ylig curves have been modified as in Jones and others (1971) to account for higher flows of short duration, less than one day. Study of the streamflow records for the Talofofo and $Y l i g$ indicated that peak flows generally persist for about two hours. The mean annual flood, therefore, with a recurrence interval of two years, approximates the 0.01 percent frequency on the duration curve: $\frac{2}{2 \times 365 \times 24}=0.011$ percent. The mean annual flood was plotted and a dashed line drawn from that point tangent to the flow-duration curve. The Ugum River streamflow records are too short to have any confidence in this modification.

Sediment rating curves were also prepared for each of the rivers (figs. 6 to 8 ). These graphs plot the mean daily or instantaneous (when only intermittent samples are available) suspended-sediment discharge against the mean daily or instantaneous water discharge to represent the average relationship between water discharge, the independent variable, and suspended-sediment discharge, the dependent variable. For the Talofofo basin a power-curve regression line through the points was determined by the least-squares method and is used to estimate instantaneous suspended-sediment discharge given an instantaneous water discharge. For the Ylig and Ugum basins the clumping of data at one end of the graphs caused a bias fit of the power-curve regression lines. Therefore, the data were fit by eye with discontinuous lines for the Ylig basin and using classaverage data points for the Ugum basin. 


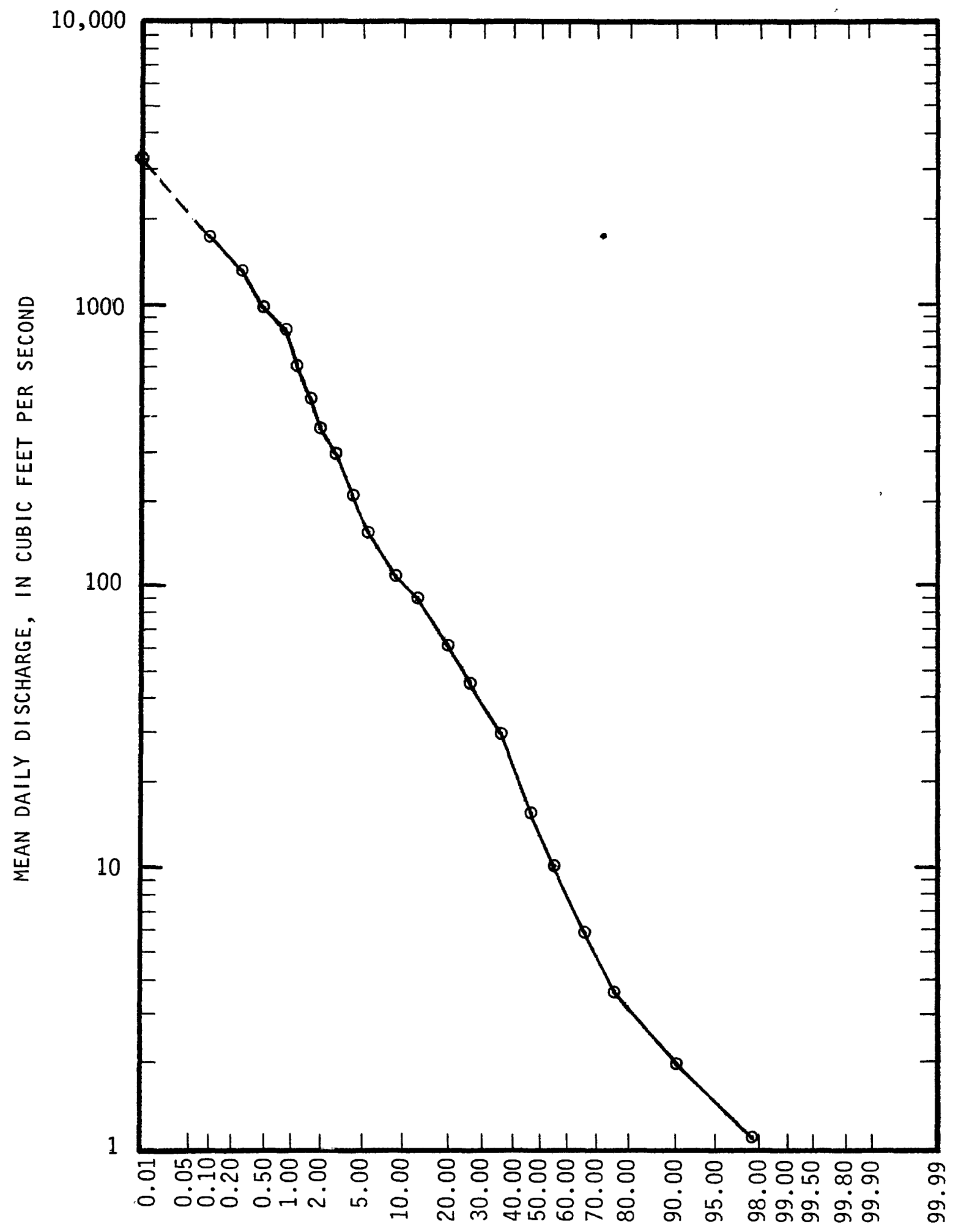

PERCENTAGE OF TIME INDICATED DISCHARGE WAS EQUALED OR EXCEEDED

Figure 3. Flow-duration curve for station 16850000, Talofofo River near Talofofo, Guam, October 1953 - September 1961. 


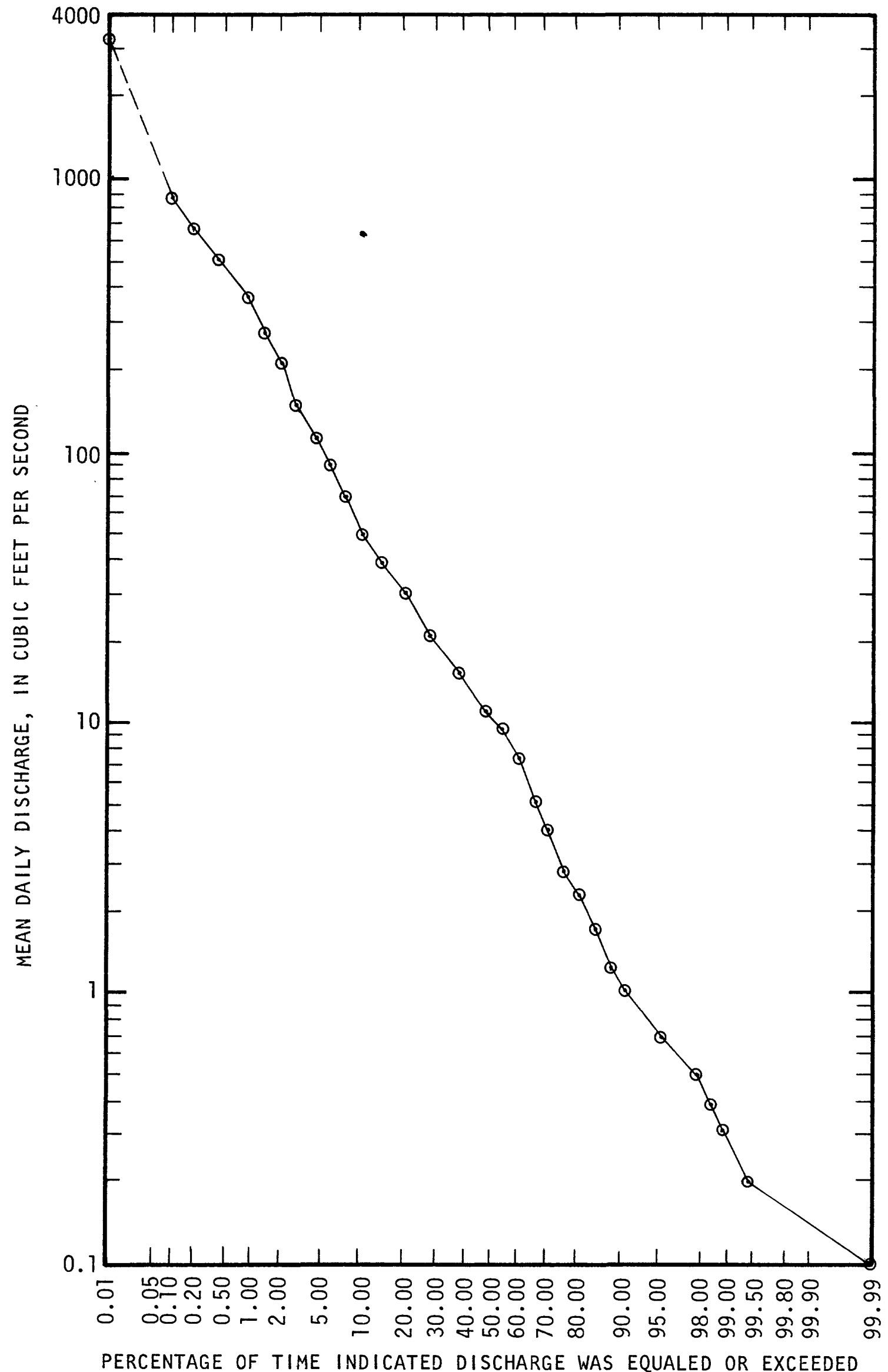

Figure 4. Flow-duration curve for station 16858000 , Ylig River near Yona, Guam, October 1953 - September 1980. 


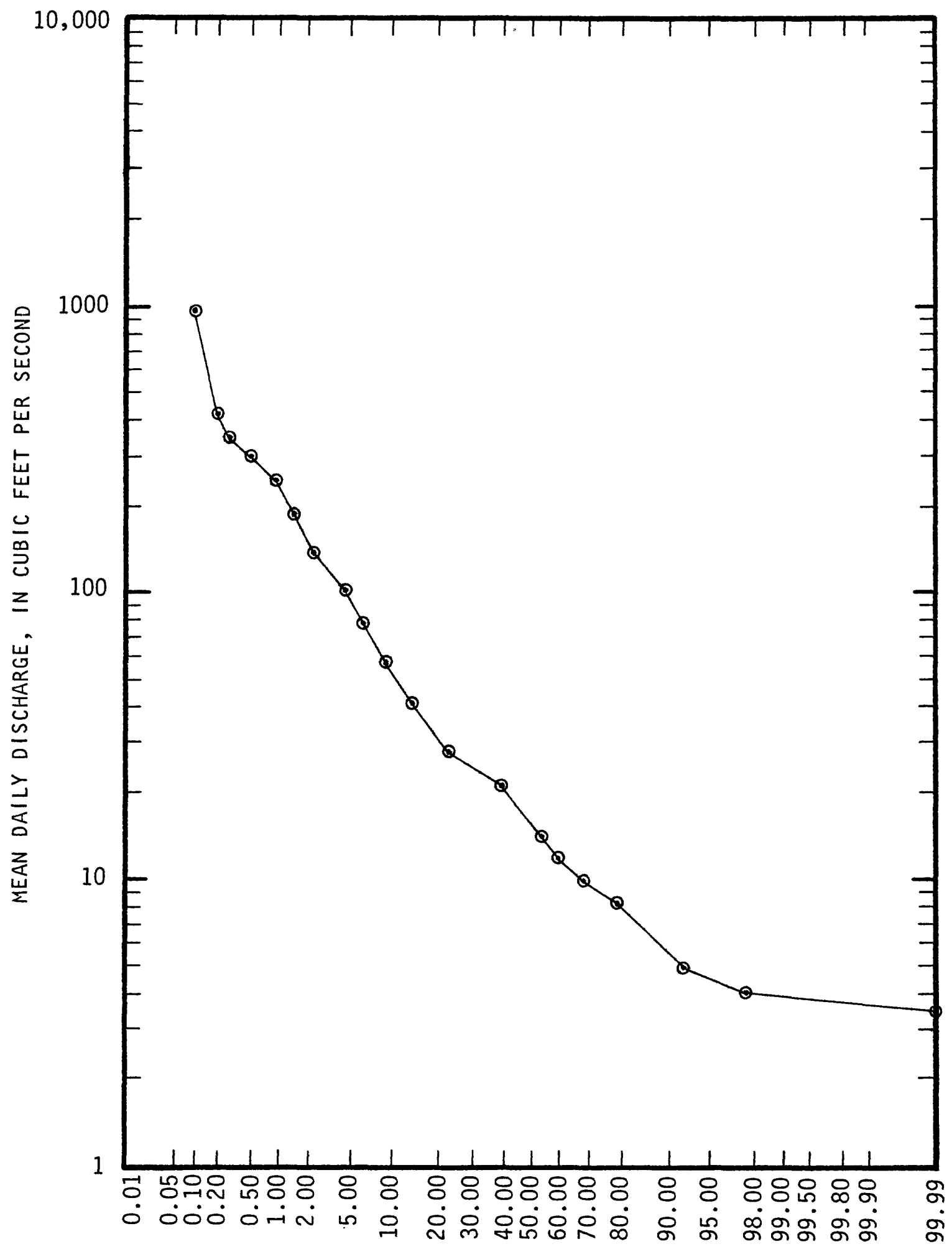

PERCENTAGE OF TIME INDICATED DISCHARGE WAS EQUALED OR EXCEEDED

Figure 5. Flow-duration curve for station 16854500, Ugum River above Talofofo Falls, Guam, October 1978September 1981. 


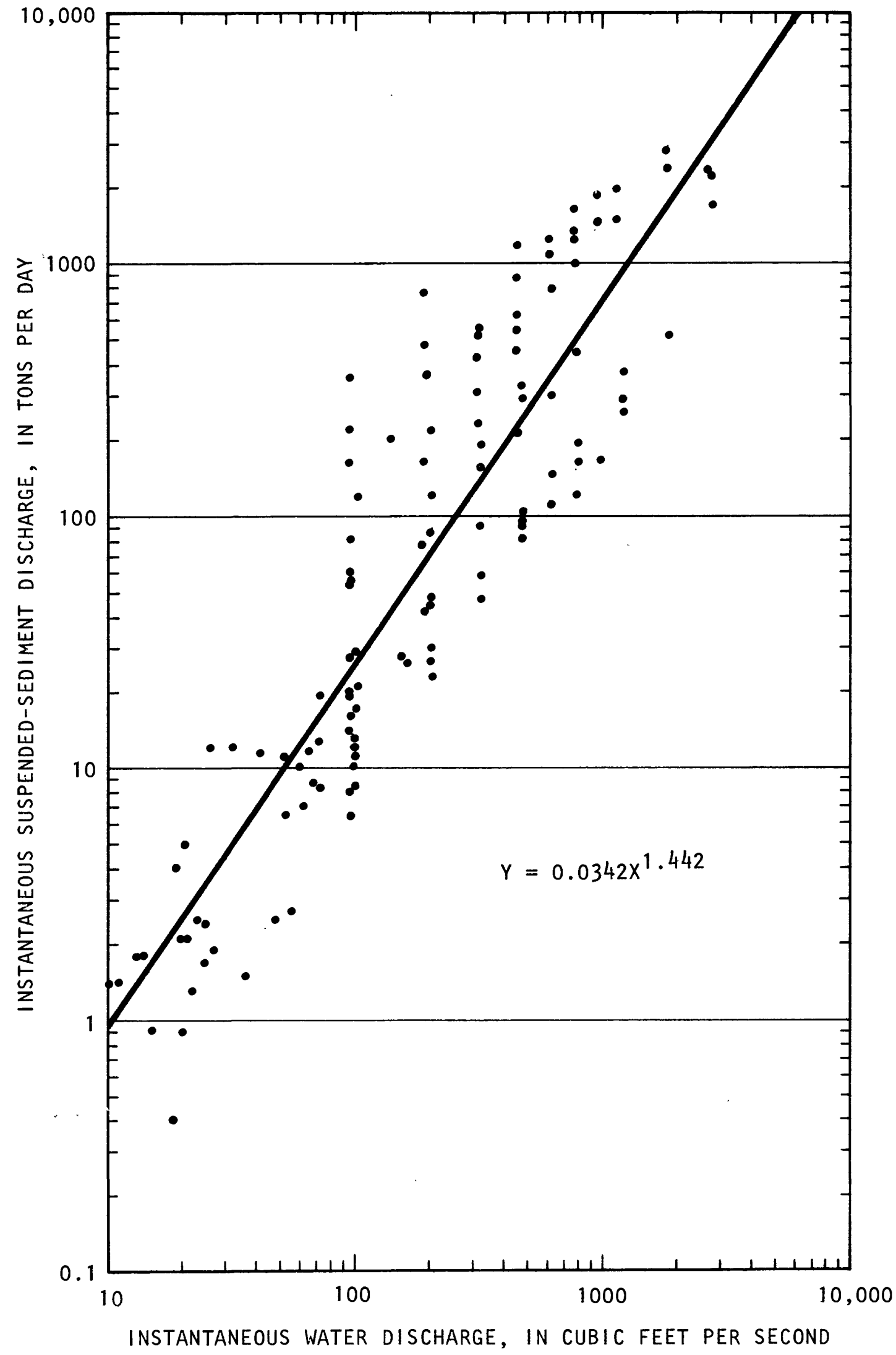

Figure 6. Instantaneous sediment rating curve for station 16850000, Talofofo River near Talofofo, Guam. 


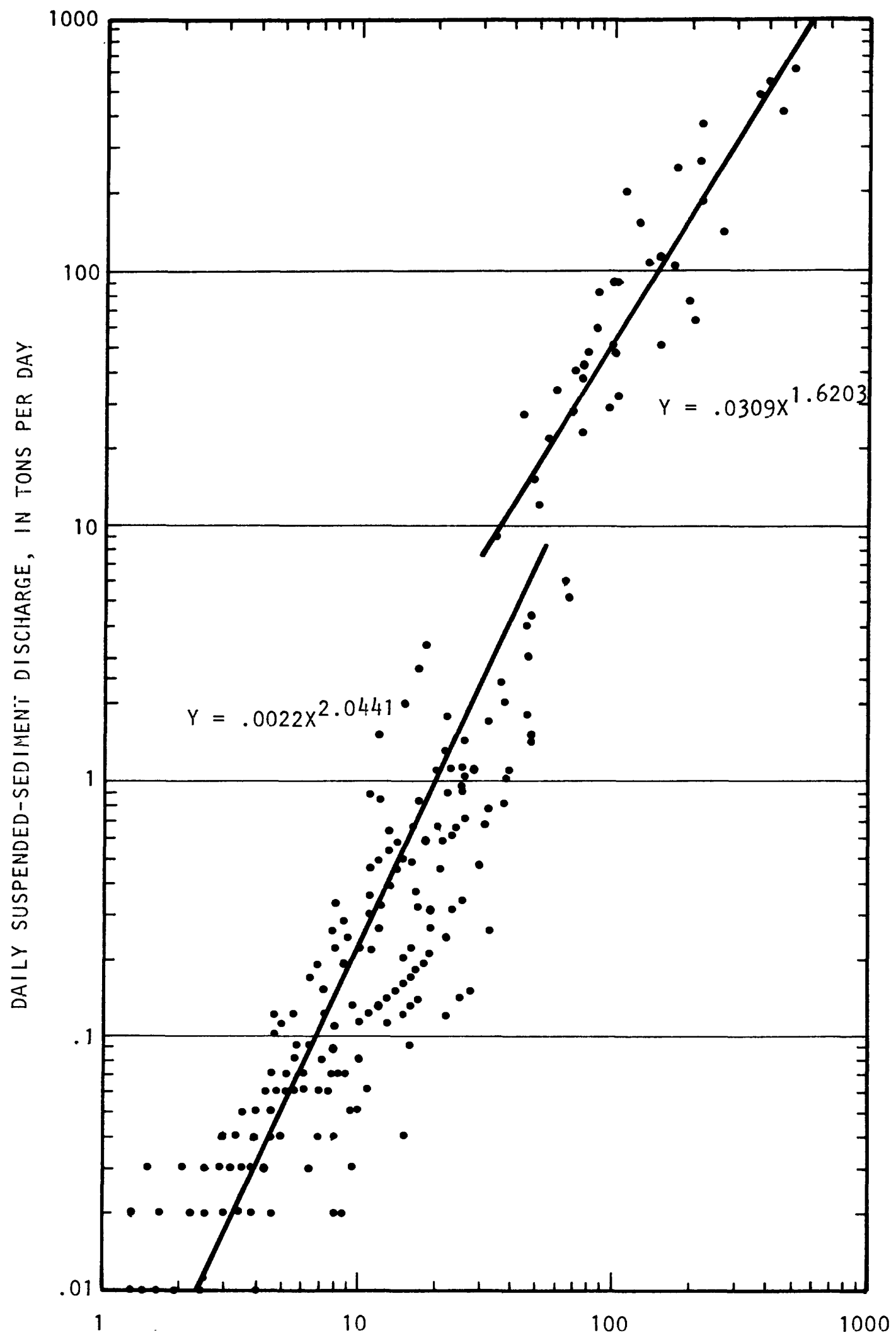

MEAN DAILY WATER DISCHARGE, IN CUBIC FEET PER SECOND

Figure 7. Daily sediment rating curve for station 16858000 , Ylig River near Yona, Guam, Aug. 1980-Sept. 1981. 


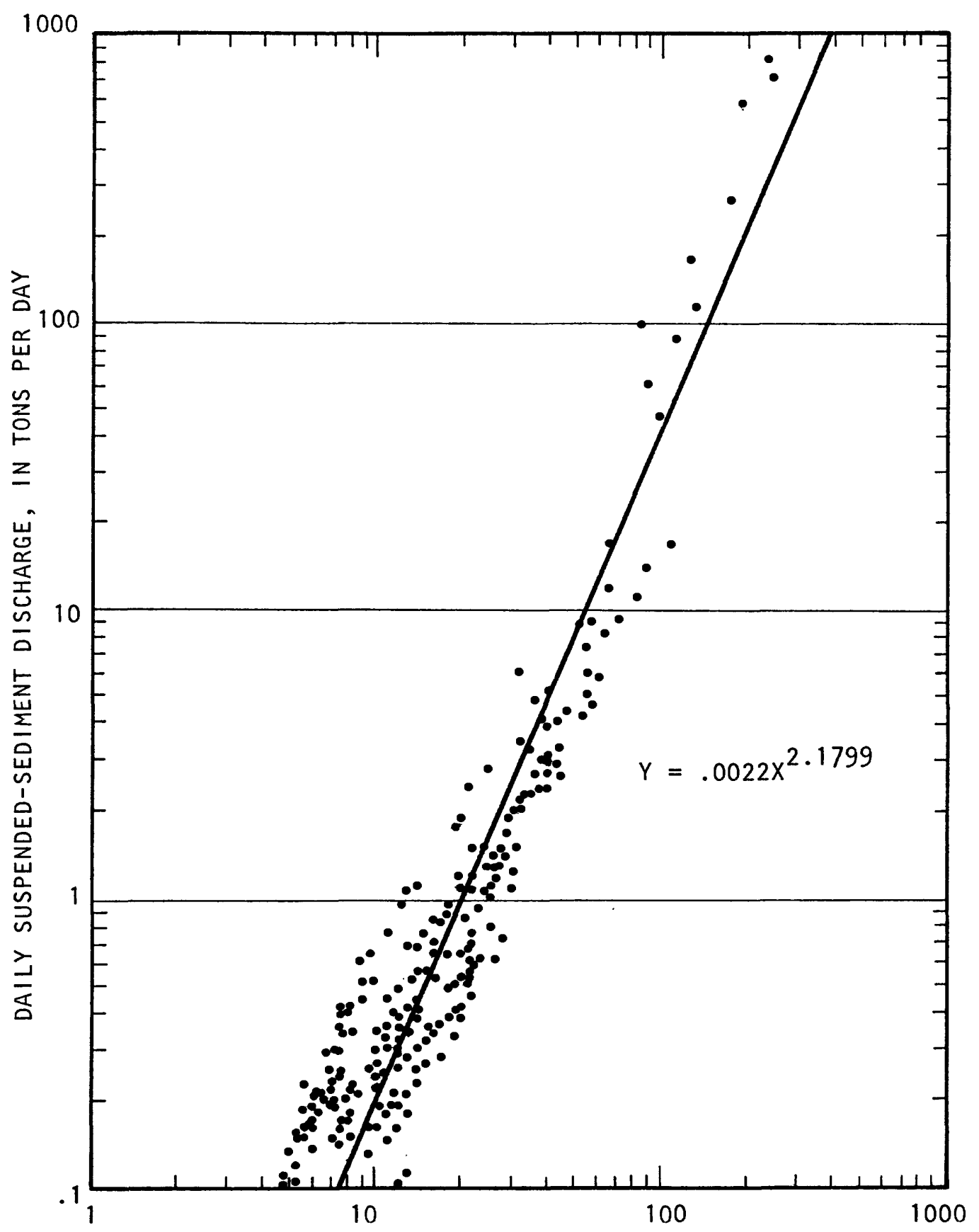

MEAN DAILY WATER DISCHARGE, IN CUBIC FEET PER SECOND

Figure 8. Daily sediment rating curve for station 16854500 , Ugum River above Talofofo Falls, October 1980June 1981 . 
To determine the mean water discharge over the period of record in acre-feet per year (acre-ft/yr), the total range of flow (in cubic feet per second) is divided into smaller ranges and the mean flow for each range is multiplied by the corresponding percentage of time that the mean flow occurs (cols. $2 \times 4$, tables 1,2 , and 3). The sum of these products multiplied by 365.25 and a unitconversion constant $(1.9835)$ yields the mean water discharge in acre-feet per year.

Sediment discharge for the midpoint of each water-discharge range is read from the sediment rating curve and listed in column 5 of tables 1 to 3 . The sum of the products of sediment discharge and the time interval (columns $2 \times 5$ ) is multiplied by 365.25 to yield the mean annual suspended-sediment load in tons per year for the period of record of the flow-duration curve. These products divided by the appropriate drainage areas give the suspended-sediment yields for the basins. Thus, the estimated mean annual suspended-sediment yield for the Talofofo basin is about 462 tons/yr/mi ${ }^{2}$; for the $\mathrm{ylig}$ basin, 1,162 tons/yr/mi ${ }^{2}$; and for the Ugum basin, 1,455 tons/yr/mi ${ }^{2}$. The Talofofo basin yield should be considered a minimum estimate due to the lack of daily data. The Ugum basin estimate is considered of only fair reliability as there are few high-flow data points available to accurately define the slope of the line in figure 8 . These estimates establish a range of suspended-sediment yield when compared with the results from the Pacific Southwest Inter-Agency Committee (PSIAC) method. Because of the limited sediment data for the Talofofo, Ylig, and Ugum River basins and the short period of streamflow records, the computed suspendedsediment yields are, at best, estimates. 
Table 1. Estimation of mean annual suspended-sediment discharge for Talofofo River

Duration table of mean daily discharge at station 16850000 and corresponding suspended-sediment discharge for

October 1953 - September 1961

\begin{tabular}{|c|c|c|c|c|c|c|c|}
\hline \multicolumn{2}{|c|}{$\begin{array}{l}\text { Col. } 1 \\
\text { Percent } \\
\text { limits }\end{array}$} & $\begin{array}{l}\text { Col. } 2 \\
\text { Percent } \\
\text { interval }\end{array}$ & $\begin{array}{l}\text { Col. } 3 \\
\text { Percent } \\
\text { mid- } \\
\text { ordinate }\end{array}$ & $\begin{array}{c}\text { col. } 4 \\
\left(\mathrm{ft}^{3} / \mathrm{s}-\mathrm{d}\right)\end{array}$ & $\begin{array}{c}\text { Col. } 5 \\
Q_{s} \\
\text { (tons/d) }\end{array}$ & $\begin{array}{c}Q_{w} \\
\text { cols. } \frac{2 \times 4}{100} \\
\left(\mathrm{ft}^{3} / \mathrm{s}-\mathrm{d}\right)\end{array}$ & $\begin{array}{c}Q_{s} \\
\text { Cols. } \frac{2 \times 5}{100} \\
(\text { tons } / d)\end{array}$ \\
\hline 0.00 & $-\quad 0.02$ & .02 & .01 & 3,300 & 4,050 & .7 & .81 \\
\hline .02 & $-\quad .05$ & .03 & .035 & 2,500 & 2,720 & .8 & $.82^{\prime}$ \\
\hline .05 & -0.1 & .05 & .075 & 1,900 & 1,830 & 1.0 & .92 \\
\hline 0.1 & -0.4 & .3 & .25 & 1,400 & 1,180 & 4.2 & 3.54 \\
\hline .4 & $-\quad .6$ & .2 & .5 & 942.5 & 665 & 1.9 & 1.33 \\
\hline .6 & -1.0 & .4 & .8 & 770 & 497 & 3.1 & 1.99 \\
\hline 1.0 & -.1 .4 & .4 & 1.2 & 600 & 347 & 2.4 & 1.39 \\
\hline 1.4 & -1.8 & .4 & 1.6 & 460 & 236 & $1.8^{\circ}$ & .94 \\
\hline 1.8 & $-\quad 2.2$ & .4 & 2.0 & 360 & 166 & 1.4 & .66 \\
\hline 2.2 & $-\quad 3.4$ & 1.2 & 2.8 & 280 & 115 & 3.4 & 1.38 \\
\hline 3.4 & -4.6 & 1.2 & 4.0 & 210 & 76 & 2.5 & .91 \\
\hline 4.6 & -7.4 & 2.8 & 6.0 & 160 & 52 & 4.5 & 1.46 \\
\hline 7.4 & -11.0 & 3.6 & 9.2 & 114 & 32 & 4.1 & 1.15 \\
\hline 11.0 & -15.0 & 4 & 13 & 88 & 22 & 3.5 & .88 \\
\hline 15 & -25 & 10 & 20 & 60 & 12.5 & 6.0 & 1.25 \\
\hline 25 & -45 & 20 & 35 & 27.8 & 4.1 & 5.6 & .82 \\
\hline 45 & -65 & 20 & 55 & 10 & .95 & 2.0 & .19 \\
\hline 65 & -85 & 20 & 75 & 3.5 & .21 & .7 & .04 \\
\hline 85 & -95 & 10 & 90 & 1.8 & .08 & .2 & .008 \\
\hline \multirow[t]{2}{*}{95} & -100 & 5 & 97.5 & 1.2 & .04 & .1 & .002 \\
\hline & & & & & TOTAL & 49.9 & 20.49 \\
\hline
\end{tabular}

Mean annual water discharge for the period 1953-61:

$$
Q_{w}=49.9 \times 365.25 \times 1.9835=36,151 \text { acre-ft/yr. }
$$

Mean annual suspended-sediment discharge:

$$
Q_{s}=20.49 \times 365.25=7,484 \text { tons/yr. }
$$

Mean annual suspended-sediment yield:

$$
7,484: 16.2=462 \text { tons } / \mathrm{yr} / \mathrm{mi}^{2} \text {. }
$$


Table 2. Estimation of mean annual suspended-sediment discharge for Ylig River

Duration table of mean daily discharge at station 16858000 and corresponding suspended-sediment discharge for October 1953 - September 1980

\begin{tabular}{|c|c|c|c|c|c|c|}
\hline $\begin{array}{l}\text { Col. } 1 \\
\text { Percent } \\
\text { limits }\end{array}$ & $\begin{array}{l}\text { Col. } 2 \\
\text { Percent } \\
\text { interval }\end{array}$ & $\begin{array}{l}\text { Col. } 3 \\
\text { Percent } \\
\text { mid- } \\
\text { ordinate }\end{array}$ & $\begin{array}{c}\text { Col. } 4 \\
\left(\mathrm{ft}^{3} / \mathrm{s}-\mathrm{d}\right)\end{array}$ & $\begin{array}{c}\text { Col. } 5 \\
Q_{s} \\
\text { (tons/d) }\end{array}$ & $\begin{array}{c}{ }_{w}^{Q_{w}} \\
\text { Cols. } \frac{2 \times 4}{100} \\
\left(\mathrm{ft}^{3} / \mathrm{s}-\mathrm{d}\right)\end{array}$ & $\begin{array}{c}Q_{s} \\
\text { Cols. } \frac{2 \times 5}{100} \\
\text { (tons } / d)\end{array}$ \\
\hline $0.00-\quad 0.02$ & .02 & .01 & 3,125 & 14,223 & .6 & 2.84 \\
\hline $.02-0.05$ & .03 & .035 & 1,700 & 5,304 & .5 & 1.59 \\
\hline $.05-0.1$ & .05 & .075 & 1,000 & 2,245 & .5 & 1.12 \\
\hline $0.1-0.4$ & .3 & .25 & 630 & 1,062 & 1.9 & 3.19 \\
\hline $.4-\quad .8$ & .4 & .6 & 448 & 611 & 1.8 & 2.44 \\
\hline $.8-1.2$ & .4 & 1.0 & 352 & 413 & 1.4 & 1.65 \\
\hline $1.2-1.8$ & .6 & 1.5 & 270 & 269 & 1.6 & 1.61 \\
\hline $1.8-2.6$ & .8 & 2.2 & 205.5 & 173 & 1.6 & 1.38 \\
\hline $2.6-3.4$ & .8 & 3.0 & 169 & 126 & 1.4 & 1.01 \\
\hline $3.4-5.4$ & 2.0 & 4.4 & 123 & 75 & 2.5 & 1.5 \\
\hline $5.4-7.4$ & 2.0 & 6.4 & 87 & 43 & 1.7 & .86 \\
\hline $7.4-10.0$ & 2.6 & 8.7 & 65 & 27 & 1.7 & .70 \\
\hline $10-15$ & 5 & 12.5 & 46 & 5.5 & 2.3 & .28 \\
\hline $15-25$ & 10 & 20.0 & 31 & 2.5 & 3.1 & .25 \\
\hline $25-45$ & 20 & 35 & 18 & .8 & 3.6 & .16 \\
\hline $45-65$ & 20 & 55 & 9 & .2 & 1.8 & .04 \\
\hline $65-85$ & 20 & 75 & 3 & .02 & .6 & .004 \\
\hline $85-95$ & 10 & 90 & 1 & .002 & .1 & .0002 \\
\hline \multirow[t]{2}{*}{$95-100$} & 5 & 97.5 & 0.5 & .0005 & .025 & .0 \\
\hline & & & & TOTAL & 28.73 & 20.62 \\
\hline
\end{tabular}

Mean annual water discharge for the period 1953-80:

$Q_{w}=28.73 \times 365.25 \times 1.9835=20,814 \mathrm{acre}-\mathrm{ft} / \mathrm{yr}$.

Mean annual suspended-sediment discharge:

$Q_{s}=20.62 \times 365.25=7,533$ tons/yr.

Mean annual suspended-sediment yield:

$7,533 / 6.48=1,162$ tons $/ \mathrm{yr} / \mathrm{mi}^{2}$. 
Table 3. Estimation of mean annual suspended-sediment discharge for Ugum River

Duration table of mean daily discharge at station 16854500 and corresponding suspended-sediment discharge for October 1978 - September 1981

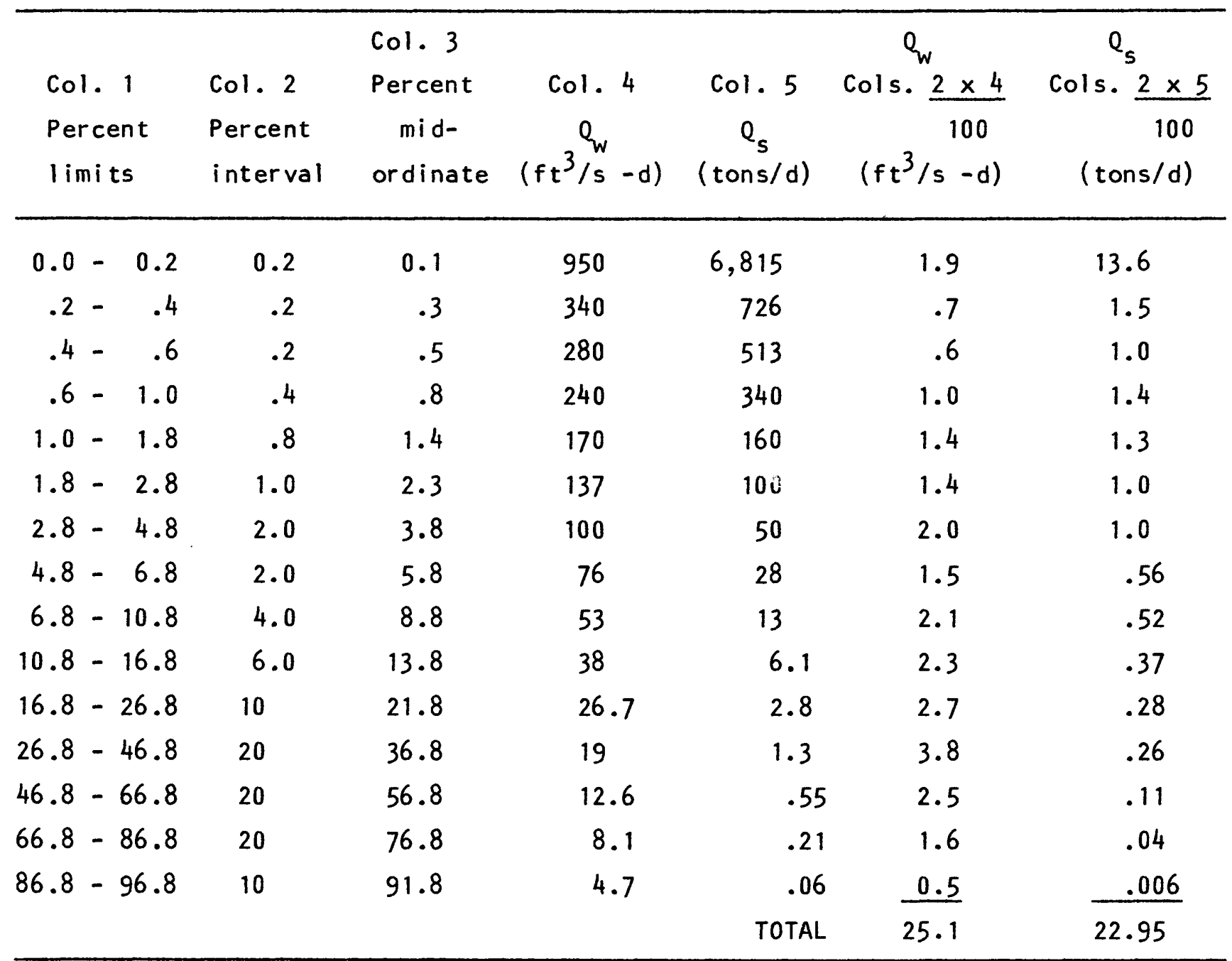

Mean annual water discharge for the period 1978-81:

$Q_{w}=25.1 \times 365.25 \times 1.9835=18,184 \mathrm{acre}-\mathrm{ft} / \mathrm{yr}$.

Mean annual suspended-sediment discharge:

$Q_{s}=22.95 \times 365.25=8,382$ tons/yr.

Mean annual suspended-sediment yield:

$8,382 / 5.76=1,455$ tons $/ \mathrm{yr} / \mathrm{mi}^{2}$. 


\section{Pacific Southwest Inter-Agency Committee (PSIAC) Method}

Because of the limited sediment data available for the Talofofo, Ylig, and Ugum Rivers, a more generalized method was used to estimate total sediment yields, (the combined bedload and suspended-sediment load per unit drainage area) for these basins. The Pacific Southwest Inter-Agency Committee (1968) developed a method referred to as the PSIAC formula to estimate sediment yields for the diverse conditions in the Pacific Southwest of the United States. This method, though developed for a region with different geology, soils, and climate, has been used successfully in Hawaii (B. L. Jones, oral communication, 1982). As Hawailan soils, geology, runoff, and rainfall characteristics are similar to those in Guam, the application of the method appeared feasible. The effect of annual droughts in Guam and the generally moderate available moisture capacity of the clay soils in the study area (Park, 1978), also parallel some of the conditions in the Pacific Southwest.

Although the PSIAC method was originally recommended for areas of 10 square miles or greater, Shown (1970) indicates good results when applied to basins between .02 and 7.5 square miles. He showed that PSIAC estimates of sediment yields correlated closely with sediment yields measured by reservoir sedimenta$t$ ion data but, that the PSIAC estimates were usually lower than the measured yields.

The PSIAC method considers nine factors in determining a sediment yield classification for a drainage area. These factors are surface geology, soils, climate, runoff, topography, ground cover, land use, upland erosion, and channel erosion and sediment transport. Characteristics of each of the nine factors, which give that factor a high, moderate, or low sediment yield level, are provided in table 4. The sediment yield characteristic of each factor is assigned a numerical value representing its relative significance in the yield rating. The yield rating is the sum of values for the appropriate characteristics for each of the nine factors. This rating is converted to a sediment yield by table 5 . The applicability of the PSIAC formula was tested by comparing its estimate of sediment yield with sedimentation data available for Fena Reservoir in southern Guam. 
Table 4. Factors affecting sediment yield

Source: Pacific Southwest Inter-Agency Comittee Report of the Water Management Subcommittee on

"Factors affecting sediment yield in the Pacific Southwest Area," and "Selection and evaluation of measures for reduction of erosion and sediment yield," 1968.

\begin{tabular}{|c|c|c|c|c|c|c|c|c|c|c|c|c|c|c|c|c|}
\hline $\begin{array}{l}\text { Sedimer } \\
\text { Yield } \\
\text { Level }\end{array}$ & & $\begin{array}{l}\text { Surface } \\
\text { geology }\end{array}$ & & Soils & & Climate & & Runoff & & Topography & & $\begin{array}{l}\text { Ground } \\
\text { cover }\end{array}$ & & $\begin{array}{l}\text { Land } \\
\text { use }\end{array}$ & $\begin{array}{l}\text { Upland } \\
\text { erosion }\end{array}$ & $\begin{array}{l}\text { Channel } \\
\text { erosion } \\
\text { and } \\
\text { sediment } \\
\text { transport }\end{array}$ \\
\hline & & $(10) *$ & & (10) & & (10) & & $(10)$ & & (20) & & $(10)$ & & $(10)$ & (25) & (25) \\
\hline High & a. & $\begin{array}{l}\text { Mar ine } \\
\text { shales } \\
\text { and re- } \\
\text { lated } \\
\text { mudstones } \\
\text { and silt- } \\
\text { stones. }\end{array}$ & $\begin{array}{l}\text { a. } \\
\text { b. }\end{array}$ & $\begin{array}{l}\text { Fine text- } \\
\text { ured; easily } \\
\text { dispersed; } \\
\text { saline- } \\
\text { alkaline; } \\
\text { high shrink- } \\
\text { swell cha: } \\
\text { racteristics. } \\
\text { Single grain } \\
\text { silts and } \\
\text { fine sands }\end{array}$ & $\begin{array}{l}\text { a. } \\
\text { b. } \\
\text { c. }\end{array}$ & $\begin{array}{l}\text { Storms of } \\
\text { several } \\
\text { day's dura- } \\
\text { tion with } \\
\text { short } \\
\text { periods of } \\
\text { intense } \\
\text { rainfall. } \\
\text { Frequent } \\
\text { intense } \\
\text { convective } \\
\text { storms } \\
\text { Freeze-thaw } \\
\text { occurrence }\end{array}$ & $\begin{array}{l}\text { a. } \\
\text { b. }\end{array}$ & $\begin{array}{l}\text { High peak } \\
\text { flows per } \\
\text { unit area } \\
\text { Large vol- } \\
\text { ume of } \\
\text { flow per } \\
\text { unit area }\end{array}$ & a. & $\begin{array}{l}\text { Steep up- } \\
\text { land slopes } \\
\text { (in excess } \\
\text { of } 30 \\
\text { percent) } \\
\text { High relief; } \\
\text { little or no } \\
\text { floodplain } \\
\text { development }\end{array}$ & a. & $\begin{array}{l}\text { Grcund } \\
\text { cover does } \\
\text { not exceed } \\
20 \text { percent } \\
\text { Vegetation } \\
\text { sparse; } \\
\text { little or } \\
\text { no litter } \\
\text { No rock in } \\
\text { surface } \\
\text { soil }\end{array}$ & $\begin{array}{l}\text { a. } \\
\text { b. } \\
\text { c. }\end{array}$ & $\begin{array}{l}\text { More than } \\
50 \text { percent } \\
\text { cultivated } \\
\text { Almost all } \\
\text { of area } \\
\text { intensively } \\
\text { grazed } \\
\text { All of area } \\
\text { recently } \\
\text { burned }\end{array}$ & $\begin{array}{l}\text { a. More than } \\
50 \text { percent } \\
\text { of the } \\
\text { area cha- } \\
\text { racterized } \\
\text { by rill and } \\
\text { gully or } \\
\text { landslide } \\
\text { erosion }\end{array}$ & $\begin{array}{l}\text { a. Eroding } \\
\text { banks con- } \\
\text { tinuously } \\
\text { or at fre- } \\
\text { quent inter- } \\
\text { vals with } \\
\text { large depths } \\
\text { and long } \\
\text { flow dura- } \\
\text { tion } \\
\text { b. Active } \\
\text { headcuts } \\
\text { and degra- } \\
\text { dation in } \\
\text { tributary } \\
\text { channels }\end{array}$ \\
\hline & & . (5) & & (5) & & (5) & & (5) & & (10) & & (0) & & (0) & $(10)$ & $(10)$ \\
\hline $\begin{array}{l}\text { Mod- } \\
\text { erate }\end{array}$ & a. & $\begin{array}{l}\text { Rocks of } \\
\text { medium } \\
\text { hardness } \\
\text { Moder- } \\
\text { ately } \\
\text { weathered } \\
\text { Moder- } \\
\text { ately } \\
\text { fractured }\end{array}$ & $\begin{array}{l}\text { a. } \\
\text { b. } \\
\text { c. }\end{array}$ & $\begin{array}{l}\text { Medium } \\
\text { textured } \\
\text { soil } \\
\text { Occasional } \\
\text { rock frag- } \\
\text { ments } \\
\text { Caliche } \\
\text { layers }\end{array}$ & $\begin{array}{l}\text { a. } \\
\text { b. }\end{array}$ & $\begin{array}{l}\text { Storms of } \\
\text { moderate } \\
\text { duration } \\
\text { and } \\
\text { intensity } \\
\text { Infrequent } \\
\text { convective } \\
\text { storms }\end{array}$ & a. & $\begin{array}{l}\text { Moderate } \\
\text { peak fl ows } \\
\text { Moderate } \\
\text { volume of } \\
\text { flow per } \\
\text { unit area }\end{array}$ & a. & $\begin{array}{l}\text { Moderate up- } \\
\text { land slopes } \\
\text { (less than } \\
20 \text { percent) } \\
\text { Moderate fan } \\
\text { or flood- } \\
\text { plain deve- } \\
\text { lopment }\end{array}$ & a. & $\begin{array}{l}\text { Cover not } \\
\text { exceeding } \\
40 \text { percent } \\
\text { Noticeable } \\
\text { litter } \\
\text { If trees } \\
\text { present } \\
\text { understory } \\
\text { not well } \\
\text { developed }\end{array}$ & $\begin{array}{l}\text { a. } \\
\text { b. } \\
\text { c. } \\
\text { d. }\end{array}$ & $\begin{array}{l}\text { Less than } \\
25 \text { percent } \\
\text { cultivated } \\
50 \text { percent } \\
\text { or less } \\
\text { recently } \\
\text { logged } \\
\text { Less than } \\
50 \text { percent } \\
\text { inten- } \\
\text { sively } \\
\text { grazed } \\
\text { Ordinary } \\
\text { road and } \\
\text { other } \\
\text { construc- } \\
\text { tion }\end{array}$ & $\begin{array}{l}\text { a. About } 25 \\
\text { percent of } \\
\text { the area } \\
\text { charac- } \\
\text { terized by } \\
\text { rill and } \\
\text { gully or } \\
\text { landslide } \\
\text { erosion } \\
\text { b. Wind } \\
\text { erosion } \\
\text { with depo- } \\
\text { sition in } \\
\text { stream } \\
\text { channels }\end{array}$ & $\begin{array}{l}\text { a. Moderate } \\
\text { flow depths, } \\
\text { medium flow } \\
\text { duration } \\
\text { with occa- } \\
\text { sionally } \\
\text { eroding } \\
\text { banks or } \\
\text { bed }\end{array}$ \\
\hline & $(0)$ & 0) & & (0) & & $(0)$ & & $(0)$ & & $(0)$ & & $(-10)$ & & $(-10)$ & (0) & $(0)$ \\
\hline Low & a. & $\begin{array}{l}\text { Massive, } \\
\text { hard for- } \\
\text { mations }\end{array}$ & $\begin{array}{l}\text { a. } \\
\text { b. } \\
\text { c. }\end{array}$ & $\begin{array}{l}\text { High percen- } \\
\text { tage of rock } \\
\text { fragments } \\
\text { Aggregated } \\
\text { clays } \\
\text { High in } \\
\text { organic } \\
\text { matter }\end{array}$ & $\begin{array}{l}\text { a. } \\
\text { b. } \\
\text { c. }\end{array}$ & $\begin{array}{l}\text { Humid climate } \\
\text { with rainfall } \\
\text { of low inten- } \\
\text { sity } \\
\text { Precipitation } \\
\text { in form of } \\
\text { snow } \\
\text { Arid cli- } \\
\text { mate, low } \\
\text { intensity } \\
\text { storms } \\
\text { Arid cli- } \\
\text { mate, rare } \\
\text { convective } \\
\text { storms }\end{array}$ & $\begin{array}{l}\text { a. } \\
\text { b. } \\
\text { c. }\end{array}$ & $\begin{array}{l}\text { Low peak } \\
\text { flows per } \\
\text { unit area } \\
\text { Low volume } \\
\text { of runoff } \\
\text { per unit } \\
\text { area } \\
\text { Rare runoff } \\
\text { events }\end{array}$ & a. & $\begin{array}{l}\text { Gentle } \\
\text { upland } \\
\text { slopes } \\
\text { (less than } \\
5 \text { percent) } \\
\text { Extensive } \\
\text { alluvial } \\
\text { plains }\end{array}$ & a. & $\begin{array}{l}\text { Area com- } \\
\text { pletely } \\
\text { protected } \\
\text { by vege- } \\
\text { tation, } \\
\text { rock frag- } \\
\text { ments, } \\
\text { litter } \\
\text { Little } \\
\text { opportu- } \\
\text { nity for } \\
\text { rainfall } \\
\text { to reach } \\
\text { erodible } \\
\text { material }\end{array}$ & $\begin{array}{l}\text { a. } \\
\text { b. } \\
\text { c. }\end{array}$ & $\begin{array}{l}\text { No culti- } \\
\text { vation } \\
\text { No recent } \\
\text { logging } \\
\text { Low } \\
\text { intensity } \\
\text { grazing }\end{array}$ & $\begin{array}{l}\text { a. No } \\
\text { apparent } \\
\text { signs of } \\
\text { erosion }\end{array}$ & $\begin{array}{l}\text { a. Wide shallow } \\
\text { channels } \\
\text { with flat } \\
\text { gradients, } \\
\text { short flow } \\
\text { duration } \\
\text { b. Channels in } \\
\text { massive } \\
\text { rock, large } \\
\text { boulders or } \\
\text { well vege- } \\
\text { tated }\end{array}$ \\
\hline
\end{tabular}

* The numbers in specific boxes indicate values to be assigned appropriate characteristics. The small letters a, b, c, refer to independent characteristics to which full value may be assigned.

** If experience so indicates, interpolation between the 3 sediment yield levels may be made. 
Table 5. PSIAC rating conversions

Source: Pacific Southwest Inter-Agency Committee Report of the Water Management Subcommittee on "Factors affecting sediment yield in the Pacific Southwest Area and selection and evaluation of measures for reduction of erosion and sediment yield," 1968.

\begin{tabular}{cc}
\hline Rating & $\begin{array}{c}\text { Sediment yield } \\
\text { (acre } \mathrm{ft} / \mathrm{mi}^{2} \text { ) }\end{array}$ \\
\hline 100 & 3.0 \\
$50-100$ & $1.0-3.0$ \\
$25-55$ & $0.5-1.0$ \\
$0-25$ & $0.2-0.5$ \\
\hline
\end{tabular}


The Fena Reservoir watershed is a sub-basin located in the western part of the Talofofo drainage area (figs. 9 and 10). The Almagosa, Imong and Maulap Rivers flow into the reservoir. The total drainage area at the dam (height, 85 $\mathrm{ft}$ and length, $1,050 \mathrm{ft}$ ) is $5.81 \mathrm{mi}^{2}$. The watershed is relatively undeveloped as it is within an ammunition storage area. The area is generally hilly to very steep and the western part is limestone rock land covered with a thin granular clay soil (figs. 11 and 12). The clay soils in the watershed are primarily of volcanic origin and are covered by a generally broad-leafed evergreen forest with a dense undergrowth of grasses and scrub (fig. 13) (Tracey and others, 1959). Small areas of open savanna occur throughout the watershed. Fires are frequent during the drought periods occurring each year.

From a Geological Survey study done by Curtis in 1979 I/, sediment accumulation was 440 acre-ft from 1949 to 1979 which amounts to $2.5 \mathrm{acre}-\mathrm{ft} / \mathrm{yr} / \mathrm{mi}^{2}$ or about 2,500 tons $/ \mathrm{yr} / \mathrm{mi}^{2}$ assuming an average deposited weight of $46 \mathrm{lb} / \mathrm{ft}^{3}$. This sediment accumulation measurement was determined by sonic soundings, and is believed to be the most reliable sediment data available.

From data provided by Curtis (written communication, 1982) it was determined that the reservoir sediment was composed of about 85 percent clay and silt and 15 percent sand and gravel. He indicated that most of the sand and gravel is transported in the tributary streams as bedload, and the silt and clay as suspended load. If it is assumed that 85 percent of the Fena Reservoir sediment was transported as suspended load and 15 percent as bedload, then from the 30 year sediment accumulation of $19,166,400 \mathrm{ft}^{3}$, the following is computed: 740 tons/yr/mi ${ }^{2}$ bedload assuming a deposited weight of $90 \mathrm{lbs} / \mathrm{ft}^{3}$; and 1,750 tons/yr/mi ${ }^{2}$ suspended-sediment load assuming a deposited weight of 37.5 Ibs/ft $\mathrm{t}^{3} \underline{2}$. This estimate of suspended-sediment yield for the Fena Reservoir drainage basin is somewhat higher than the range (462 to 1,455) calculated for the Talofofo, Ylig, and Ugum basins by the flow-duration sediment-rating-curve method.

1/ Curtis, W. F., written communication, 1982.

2/ Particle size analysis from Curtis, W. F., written communication, 1982. 


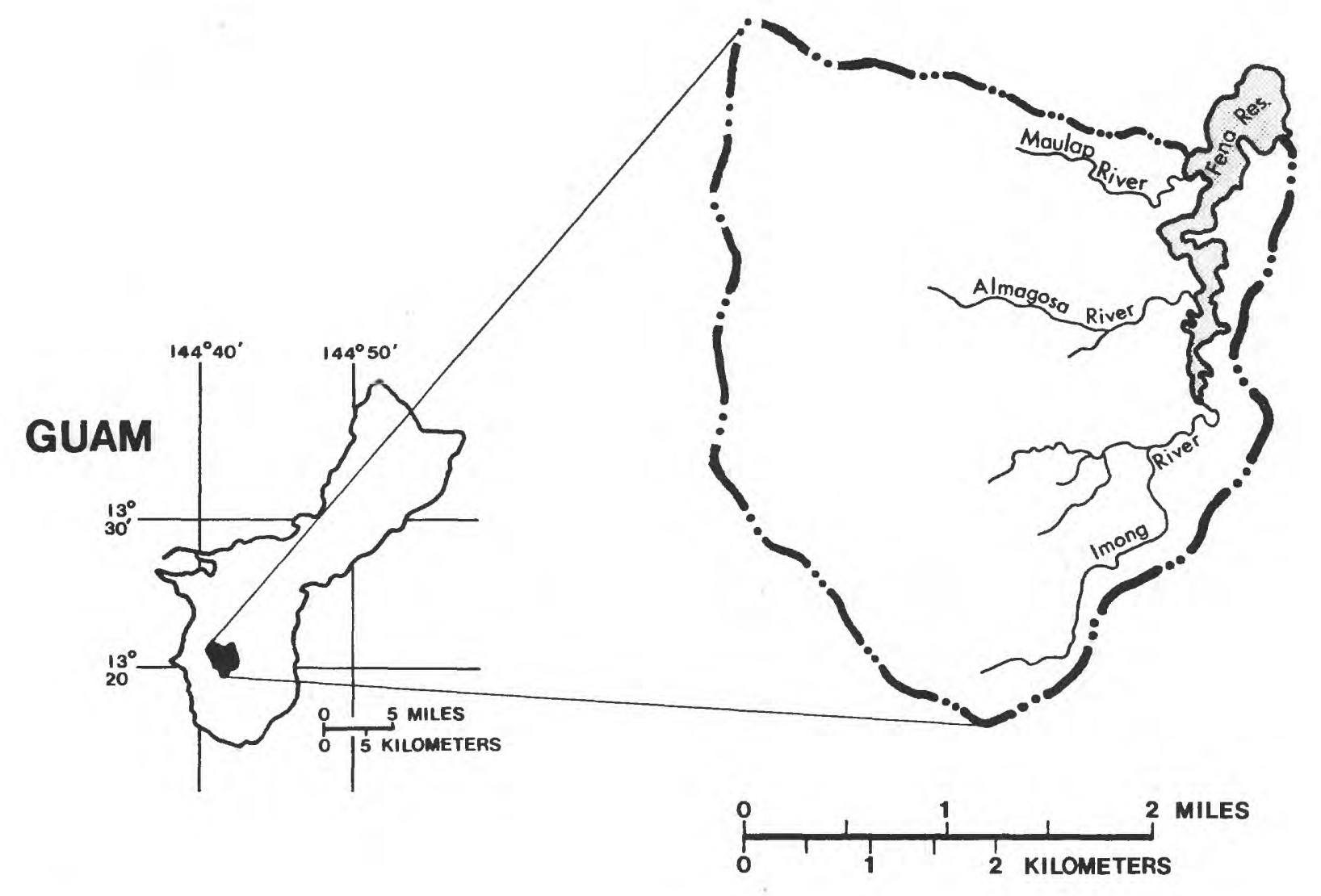

Figure 9. Location of Fena Reservoir drainage area, (from Curtis, W. F., written communication, 1982). 


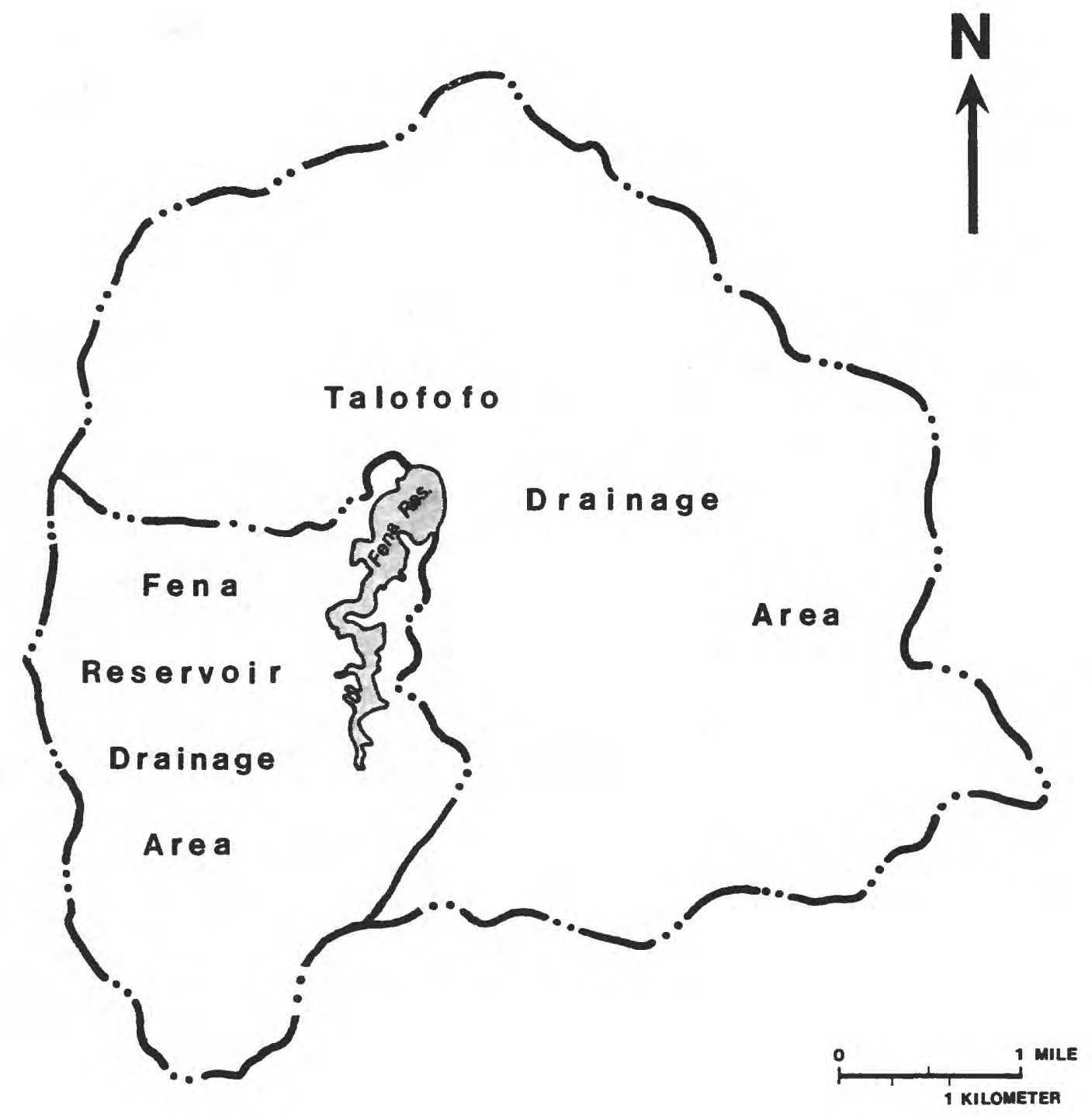

Figure 10. Location of Talofofo and Fena Reservoir drainage areas. 


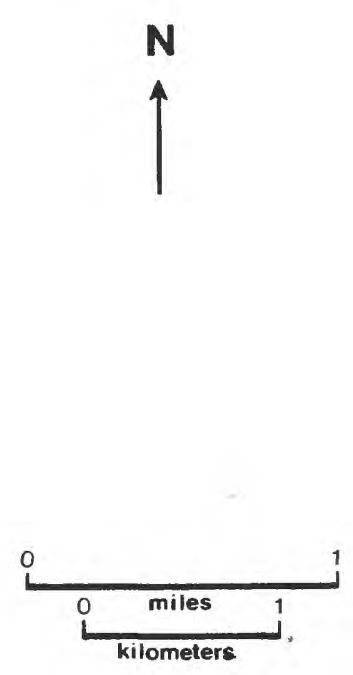

Figure 11. Geology of Fena Reservoir drainage area.

Alluvium
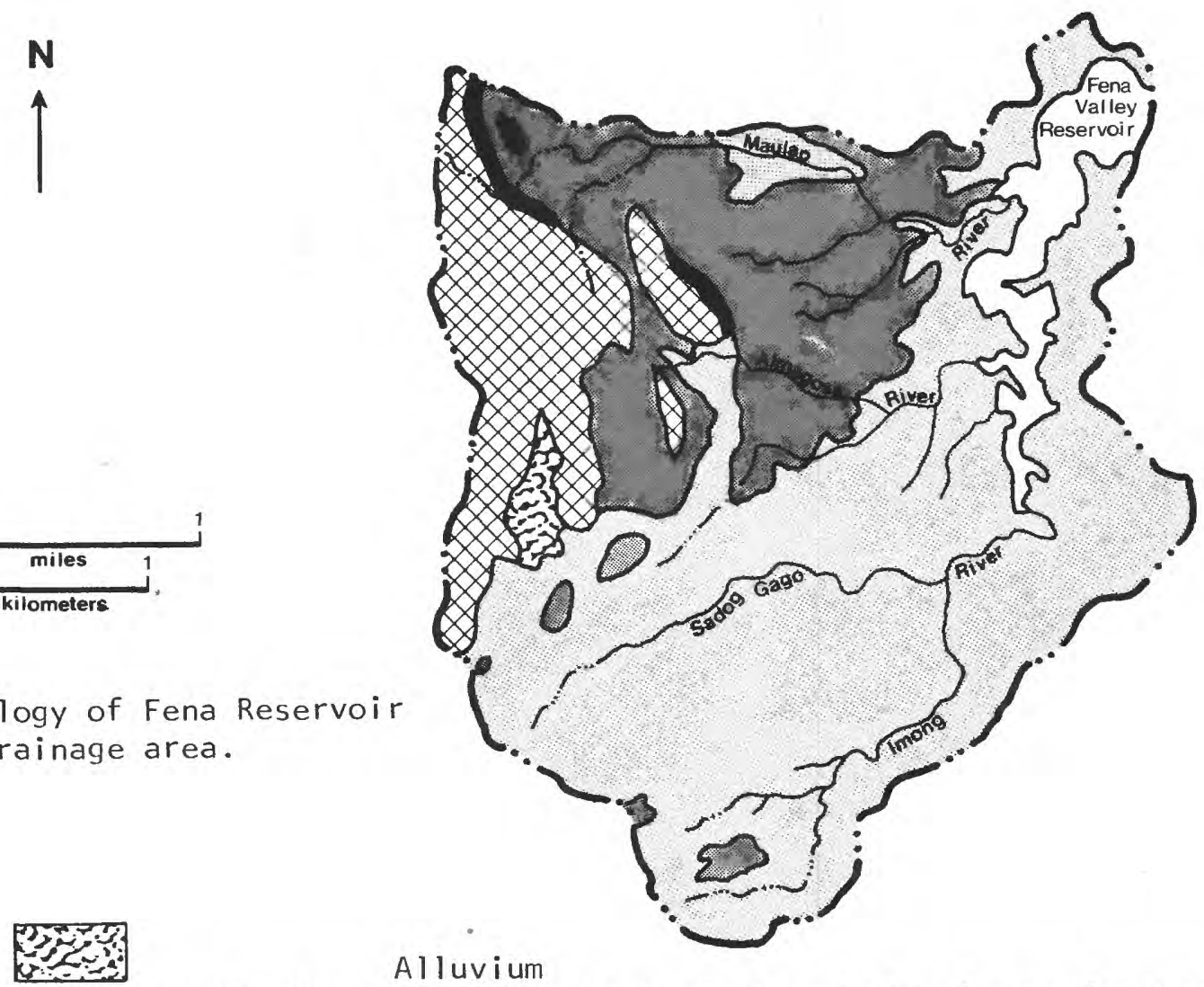

Alluvium clay deposits mostly 30 to 100 feet thick; muck and clay in marshy estuarine deposits on the west coast, and clay fill in large sinks in limestone areas.

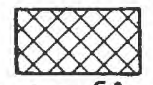

Alifan Limestone

Massive, coarse to fine-grained recrystallized limestone, generally pale-pink, buff, or white, but locally red, yellow, or brown. Characterized by dominance of stick-like Porites and Acropora and by long calcite tubes formed by burrowing worms or gastropods. Locally argillaceous above unconformable contact with underlying Umatac and Alutom Formations, and above conformable contact with underlying Tal isay Member.

\section{Tal isay Member of Al ifan Formation}

Yellow, green, and red clay and lenticular clayey gravel and conglomerate; some gray to green marl containing stick-like Porites, and Acropora, and some interbedded limestone lenses. Generally unconformable with the underlying Umatac and Alutom Formations; locally overlies the Bonya Limestone. Thickness irregular, 2 to 30 feet.

\section{Umatac Formation}

Dandan Flow Member, compact, medium to coarse-grained, porphyritic basalt flows separated from the underlying Bolanos Conglomerate Member by a flow breccia approximately 10 feet thick; maximum thickness of member about 50 feet. Aggregate thickness of formation about 2,200 feet.

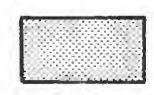

Umatac Formation

Bolanos Pyroclastic Member, basal part consists of massive lapilli breccia and marine conglomerate containing fragments of the Maemong Limestone Member; upper part consists of tuffaceous sandstone and shale interbedded with minor amounts of conglomerate. Maximum thickness about 750 feet. 


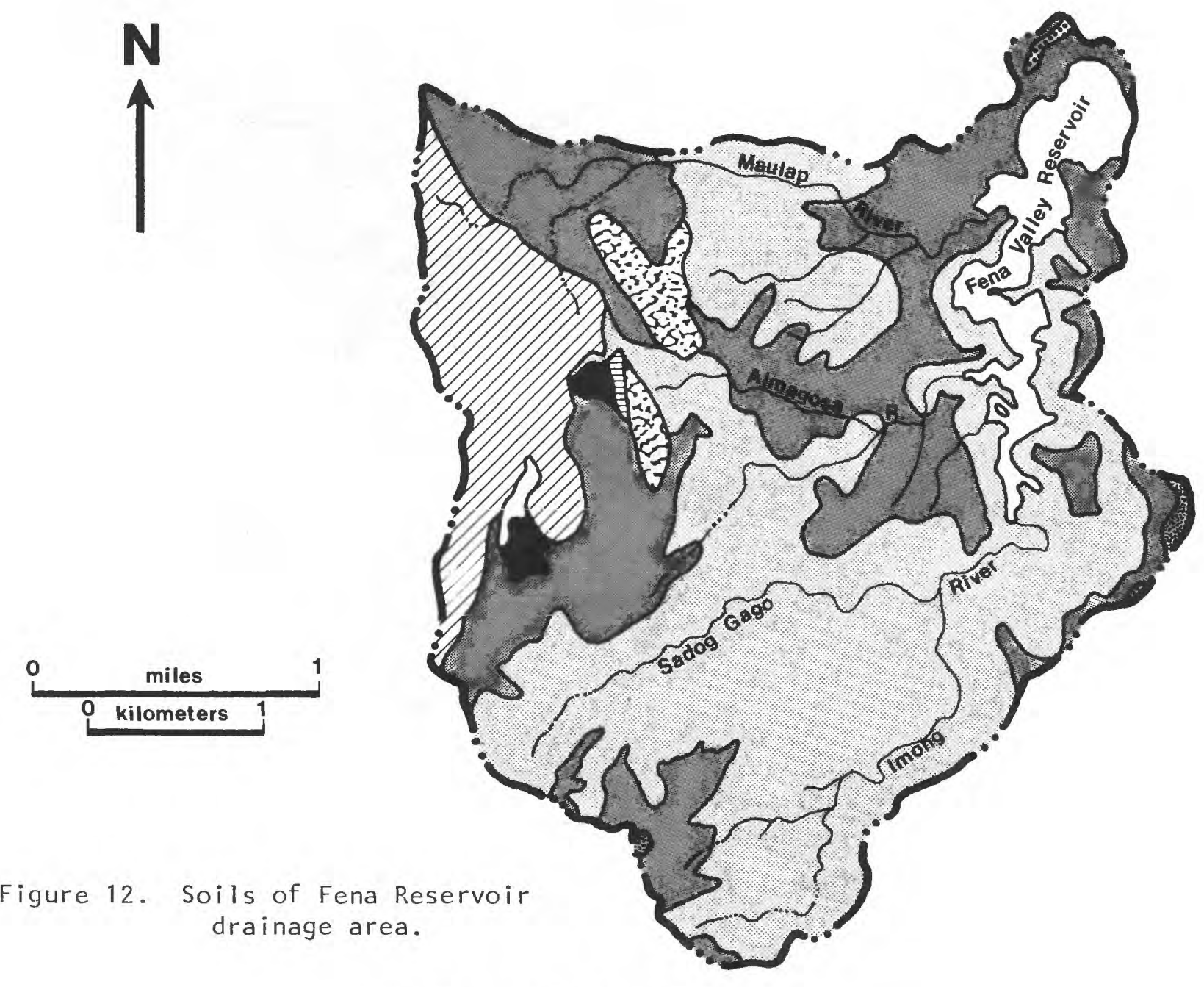

UPLAND SOILS (ON LIMESTONE)

Saipan-Yona-Chacha $\mathrm{Clays}$

Chacha-Saipan clays with a shallow brownish Lithosol (Yona clay) on many of the narrow convex ridgetops and steep slopes; soil depth similar to Chacha-Saipan clays, except Yona clay which generally grades into clayey limestone at about 12 to 24 inches below surface; reaction of Yona clay is thus alkaline or calcareous; prevailing surface gradient 8 to 25 percent.

\section{Yona-Chacha Clays}

Yona clay is on most narrow convex ridgetops and steep side slopes, with Chacha on intervening slopes; also small areas of shallow stony phase Saipan clay; depth of soil with convex surface is generally less than 2 or 3 feet, with concave surface it is generally more than 3 feet; slopes range from 25 to more than 100 percent but prevailing surface gradient is commonly 30 to 65 percent.

\section{Atate-Agat Clay, Rolling}

Remnant benches or small mesas of an old red, granular, porous, acid Latosol (Atate clay) with deep, reddish, mottled, plastic to hard clay $C$ horizon, pale yellow, olive, or gray in lower part; and its truncated counterpart (Agat clay) with similar $C$ horizon of saprolitic clay, ranging in depth from a few feet to about 100 feet and averaging about 50 feet; prevailing surface gradient of Atate clay is 1 to 8 percent, and of Agat clay 8 to 15 percent. 


\section{UPLAND SOILS (ON VOLCANIC ROCKS)}

$$
\text { Agat-Asan-Atate Clays, Hilly }
$$

Atate-Agat clays and a dark grayish-brown Regosol (Asan clay) developed in more severely truncated saprolite (similar to lower part of $C$ horizon in Atate-Agat clay); soil depths similar to those of Atate-Agat clay, except Asan clay which ranges from a few feet in depth to generally less than 50 feet; prevailing surface gradient 15 to 50 percent.

Agat-Asan Clays and Rock Outcrop
Very Hilly to Steep

Chiefly of the truncated Latosol (Agat clay) and the Regosol (Asan clay) with some un-named dark grayish-brown Lithosols and scattered small areas of volcanic rock outcrop (basalt and bedded tuffs); depth to rock ranges from 0 to 50 or more feet and averages perhaps 20 to 35 feet; prevailing surface gradient 35 to more than 100 percent.

Pago Clay

Brownish, granular to firm and plastic alluvial clay, with gray mottling to within 24 to 30 inches of the surface; generally alkaline to neutral; soil depth is generally more than 10 and less than 150 feet; moderately well drained; subject to occasional flooding; prevailing surface gradient 1 to 3 percent.

\section{Inarajan Clay}

Similar to Pago clay but lower, wetter, and shallower (thins out on coastal sands and bedrock); water table at or near the surface (within 30 inches) most of the time; poor drainage mottlings (gray) within 6 to 12 inches of the surface; depth to sand or bedrock ranges from 3 to 25 or more feet; reaction is alkaline in water saturated zone; poorly drained; frequently flooded; prevailing surface gradient 0 to 1 percent.

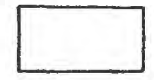

Muck

Black to brown, soft muck and peat, with some clay and silt; depth to underlying material (chiefly limesand or shelly clay) ranges from 3 to 20 feet, averages 5 to 10 feet; alkaline reaction below the water table, which is generally at or near the surface; prevailing surface gradient is level or very nearly level.

\section{MISCELLANEOUS LAND TYPES}

\section{EIIIT Limestone Rock Land, Steep}

Patches of thin reddish or brownish granular clay among exposures of limestone bedrock. Consists largely of steep ridges, scarps, and cliffs; prevailing surface gradient 25 to more than 100 percent, with many scarps or cliffs nearly vertical. 

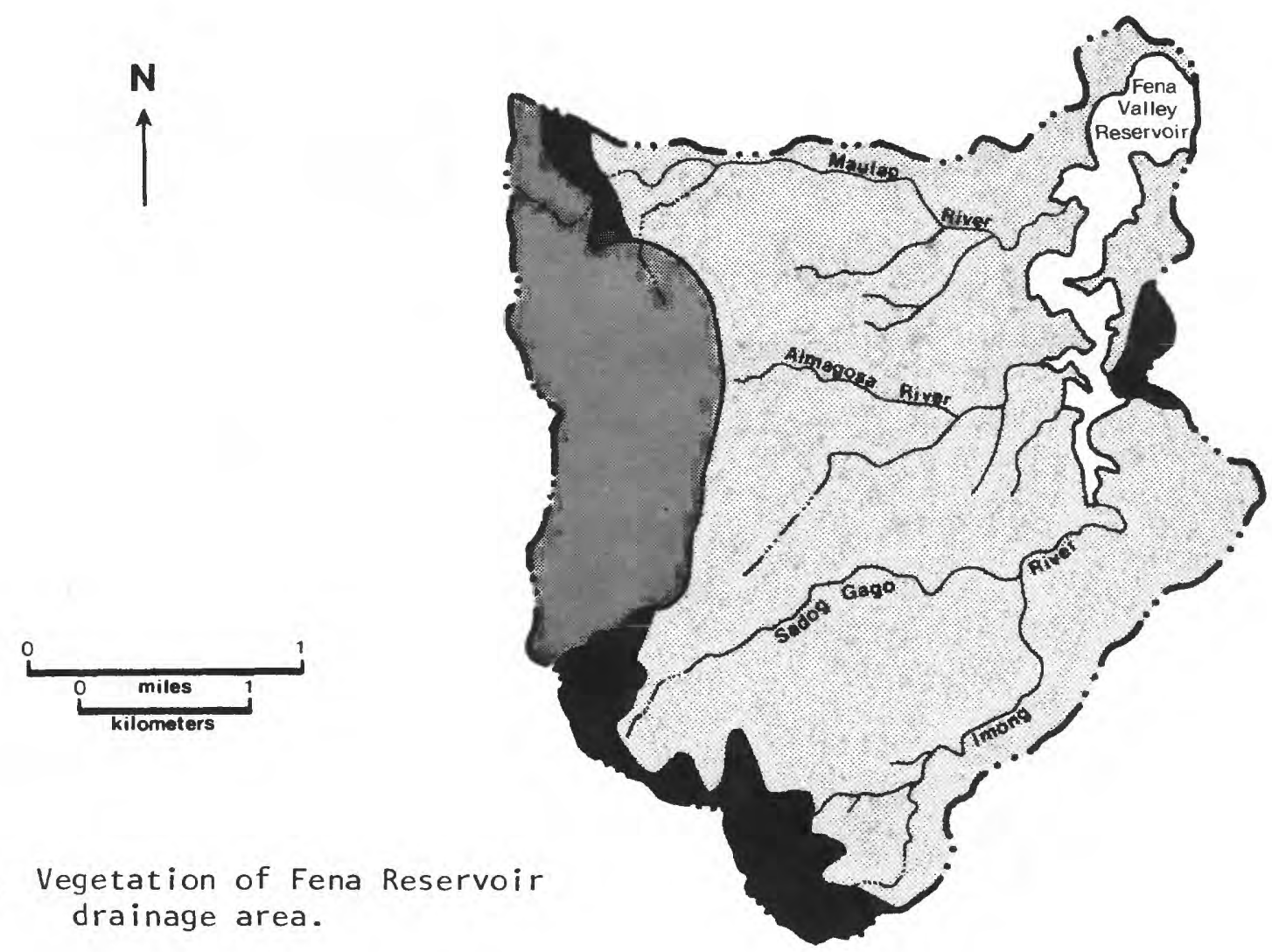

Figure 13. Vegetation of Fena Reservoir drainage area.

Mixed Forest on Limestone Plateaus and Cliffs

Basically a moist broad-leafed evergreen forest, mostly dominated by wild breadfruit (Artocarpus or "dugdug") and banyan (Ficus); in some large areas, by screwpine (Pandanus), or locally by other species. Varies to a dense scrub on edges and faces of cliffs and near the sea; where once cleared and abandoned, or where badly damaged by war activities, it is principally a dense scrub forest of hibiscus and other secondary trees with scattered large dead or half-dead trunks towering above the general level of growth. Canopy irregular, up to 75 feet high; trees 6 inches and more in diameter are fairly closely to widely spaced; undergrowth sparse where forest is little disturbed, to very dense where recent disturbance has been great.

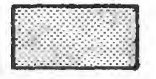

Mixed Forest on Volcanic Soil in Ravines and on Limestone Outcrops in Valleys

Basically a moist broad-leafed evergreen forest dominated locally by hibiscus or by screw-pine (Pandanus), rarely by wild breadfruit (Artocarpus or "dugdug"); usually very mixed, commonly containing betel palm (Areca) and with breadfruit scarce or absent; varies commonly to a dense scrub of limon de china (Triphasia) or to patches of reed marsh or hibiscus scrub. Coconut occasional to locally common. Stature generally low (seldom over $40 \mathrm{feet}$ ), canopy dense to irregular, large trees locally common and closely spaced; undergrowth generally dense, usually spiny. Unit may include small areas of savanna.

\section{Savanna}

Mosaic of several kinds of grassland and herbaceous vegetation and erosion scars with shrubs and tangled ferns. Swordgrass (Miscanthus) dominant over large areas. Small ironwood (Casuarina) trees scattered in many parts, locally forming sparse woodland. Swordgrass very dense. Unit may include small areas of ravine forest. 
PSIAC evaluations of the surface geology, soils and ground-cover factors for the Fena watershed were made from maps prepared by the U.S. Army in the publication, "Military Geology of Guam, Mariana Islands" (Tracey and others, 1959). The information presented in figures 11 to 13 was compiled from these maps and drainage area maps found in "A Report Covering the Surface Water Survey of the Island of Guam," by Austin, Smith and Associates, Inc. (1968). Verification of the vegetation map was done by inspection of a set of aerial photographs taken in 1975.

Evaluations were made of the remaining factors:

(1) topography from a 1:50,000-scale topographic map of Guam prepared by the Geological Survey in 1978;

(2) climate from Geological Survey rainfall data at several stations in southern Guam, as well as from a narrative by David I. Blumenstock, found in the "Military Geology of Guam" (Tracey and others, 1959) and from the "Hydrology of Guam," U.S. Geological Survey Professional Paper 403-H, (Ward, and others, 1965);

(3) runoff from an analysis of Geological Survey streamflow data in the study area and information found in "Hydrology of Guam";

(4) channel-erosion and sediment-transport from streamflow data, channel cross-sections, and information from Geological Survey field personnel in Guam; and

(5) land use and upland erosion from inspection of the 1975 aerial photographs.

The PSIAC values for the climate, runoff, topography, land use, upland erosion, channel erosion and sediment transport categories were determined by the use of table 4 and the above information sources. The surface geology, soils, and ground-cover factors were evaluated by placing a grid over each of the maps (figs. 11 to 13) and determining the proportion of the total area covered by each particular rock, soil, or vegetation type. The percentage of area covered by each type was multiplied by a corresponding PSIAC value from table 4 . The $P S I A C$ value for the factor in the drainage area was the sum of the products. A sample computation is given in table 6. Table 7 lists all the factors and PSIAC numerical values assigned to each. The application of this method indicates an annual sediment yield of 2 acre- $\mathrm{ft} / \mathrm{mi}^{2}$ from the Fena Reservoir basin. This is a reasonable estimate based on the reservoir sedimentation data from the 1979 survey by Curtis $\left(2.5\right.$ acre- $\left.\mathrm{ft} / \mathrm{mi}^{2}\right)$. 
Table 6. Sample computation of PSIAC value for Fena soils (fig. 12)

\begin{tabular}{lcccc}
\hline \multicolumn{1}{c}{ Soil type } & $\begin{array}{c}\text { Number of } \\
\text { grid blocks }\end{array}$ & $\begin{array}{c}\text { Percentage } \\
\text { of area }\end{array}$ & $\begin{array}{c}\text { PSIAC } \\
\text { value }\end{array}$ & $\begin{array}{c}\text { PSIAC value X } \\
\text { percentage } \\
\text { area }\end{array}$ \\
\hline Saipan-Yona-Chacha clay & 7 & 0.002 & 10 & 0.02 \\
Yona-Chacha clay & 87 & .025 & 10 & .25 \\
Atate-Agat clay & 13 & .04 & 10 & .04 \\
Agat-Asan-Atate clay & 1,165 & .328 & 10 & 3.28 \\
Agat-Asan clay & 1,851 & .52 & 5 & 2.6 \\
Pago clay & 7 & .002 & 7.5 & .015 \\
Inarajan clay & 29 & .008 & 10 & .08 \\
Muck & 10 & .003 & 10 & .03 \\
Limestone rock land & 388 & .109 & 5 & .545 \\
Totals & & & & 6.86 \\
PSIAC value for Fena soils $=6.9$ & & & & \\
\hline
\end{tabular}

Table 7. PSIAC values for factors affecting sediment yield

\section{Fena}

\begin{tabular}{lc}
\hline Surface geology & 4 \\
Soils & 7 \\
Ground cover & -9.6 \\
Climate & 10 \\
Runoff & 10 \\
Topography & 5 \\
Land use & 15 \\
Upland erosion & \\
Channel erosion and & 25 \\
sediment transport -- & \\
Total & \\
\hline
\end{tabular}

Note: From table 5 the basin is within the 75-100 rating which translates to a mean annual sediment yield of 2.0 acre- $\mathrm{ft} / \mathrm{mi}^{2}$. 
This same procedure was applied to the Talofofo, Ylig, and Ugum basins and their values of the PSIAC factors are listed in table 8 . Measuring the drainage areas for each basin upstream of the streamflow gaging station, the following sediment yields are derived:

Talofofo drainage area: $16.2 \mathrm{mi}^{2} \times 1.2$ acre-ft/mi ${ }^{2}=19$ acre-ft;

Ylig drainage area: $6.48 \mathrm{mi}^{2} \times 1.4 \mathrm{acre}-\mathrm{ft} / \mathrm{mi}^{2}=9$ acre-ft;

Ugum drainage area: $5.76 \mathrm{mi}^{2} \times 1.2 \mathrm{acre}-\mathrm{ft} / \mathrm{mi}^{2}=7$ acre-ft.

Using the same distribution of. 85 percent suspended material at $38 \mathrm{lb} / \mathrm{ft}^{3}$ and 15 percent bed material at $90 \mathrm{lbs} / \mathrm{ft}^{3}$ assumed in the Fena Reservoir watershed, and the conversion of acre- $\mathrm{ft}$ to $\mathrm{ft}^{3}$, the resultant computation gives a mean annual sediment yield of 1,200 tons $/ \mathrm{yr} / \mathrm{mi}^{2}$ for the Talofofo, $1,385 \mathrm{tons} / \mathrm{yr} / \mathrm{mi}^{2}$ for the $\mathrm{Ylig}$, and $1,210 \mathrm{tons} / \mathrm{yr} / \mathrm{mi}^{2}$ for the Ugum basins. These figures represent both suspended-sediment and bed material. By assuming that 85 percent of the yields are transported as suspended load, the mean annual suspended-sediment yields for the Talofofo, $\mathrm{Ylig}$, and Ugum basins are 845,977 , and $855 \mathrm{tons} / \mathrm{yr} / \mathrm{mi}^{2}$ respectively. The estimates of mean annual suspended-sediment yield from the flow-duration sediment-rating-curve method of 462 tons/yr/mi ${ }^{2}$ for the Talofofo, 1,162 tons/yr/mi ${ }^{2}$ for the $\mathrm{Y} 1 \mathrm{ig}$, and 1,455 tons/yr/mi ${ }^{2}$ for the Ugum basins, together with the PSIAC estimates, establish a reasonable range of suspendedsediment yields for the basins.

Table 8. PSIAC values for factors affecting sediment yield

\begin{tabular}{lccc}
\hline & Talofofo & Ugum & Ylig \\
\hline Surface geology & 1.9 & 2 & 1.6 \\
Soils & 8.4 & 8.5 & 9 \\
Ground cover & -8.4 & -8.5 & -5.8 \\
Climate & 10 & 10 & 10 \\
Runoff & 10 & 10 & 10 \\
Topography & 15 & 15 & 15 \\
Land use - & 5 & 5 & 5 \\
Upland erosion & 15 & 15 & 20 \\
Channel erosion and & 20 & 20 & $\overline{79.8}$ \\
sediment transport -- & $\overline{76.9}$ & $\overline{77}$ & \\
Totals &
\end{tabular}

Note: From table 5 each basin is within the 75-100 rating, which translates, to a mean annual sediment yield of about 1 acre-ft/mi ${ }^{2}$ for each of the basins. 
The results of the flow-duration sediment-rating-curve and PSIAC methods in estimating both suspended-sediment and total sediment yields from the Fena Reservoir, Talofofo, Ylig, and Ugum basins are credible in light of data available for several similar basins on 0ahu, Hawaii. A reprint (table 9) of a table from a report by Jones and others (1971) indicates that the range of suspendedsediment yields of $462-845$ tons $/ \mathrm{yr} / \mathrm{mi}^{2}, 977-1,162$ tons $/ \mathrm{yr} / \mathrm{mi}^{2}, 855-1,455$ tons/yr/mi ${ }^{2}$, from the Talofofo, $Y l i g$, and Ugum drainage areas respectively, compares well with suspended-sediment yields from several Oahu basins which range from 630 to 1,400 tons $/ y r / \mathrm{mi}^{2}$. These basins generally have similar topography, steep headwater and side ridges, active head cuts, predominantly clay soils derived from volcanic rock, similar climate in terms of temperature, annual rainfall, storm intensities and duration, and similar runoff characteristics with high, short-duration peak flows.

The total mean annual sediment yields of 1,200 tons/yr/mi ${ }^{2}(1.2$ acre$\left.\mathrm{ft} / \mathrm{yr} / \mathrm{mi}^{2}\right)$ for the Talofofo, $1,385 \mathrm{tons} / \mathrm{yr} / \mathrm{mi}^{2}\left(1.4 \mathrm{acre}-\mathrm{ft} / \mathrm{yr} / \mathrm{mi}^{2}\right)$ for the $\mathrm{Ylig}$, and 1,210 tons/yr/mi ${ }^{2}\left(1.2 \mathrm{acre}-\mathrm{ft} / \mathrm{yr} / \mathrm{mi}^{2}\right)$ for the Ugum basin are also consistent with the yields from the 0ahu basins which range from 785 to 2,200 tons/yr/mi ${ }^{2}\left(0.5\right.$ to $\left.6.2 \mathrm{acre}-\mathrm{ft} / \mathrm{yr} / \mathrm{mi}^{2}\right)$. 


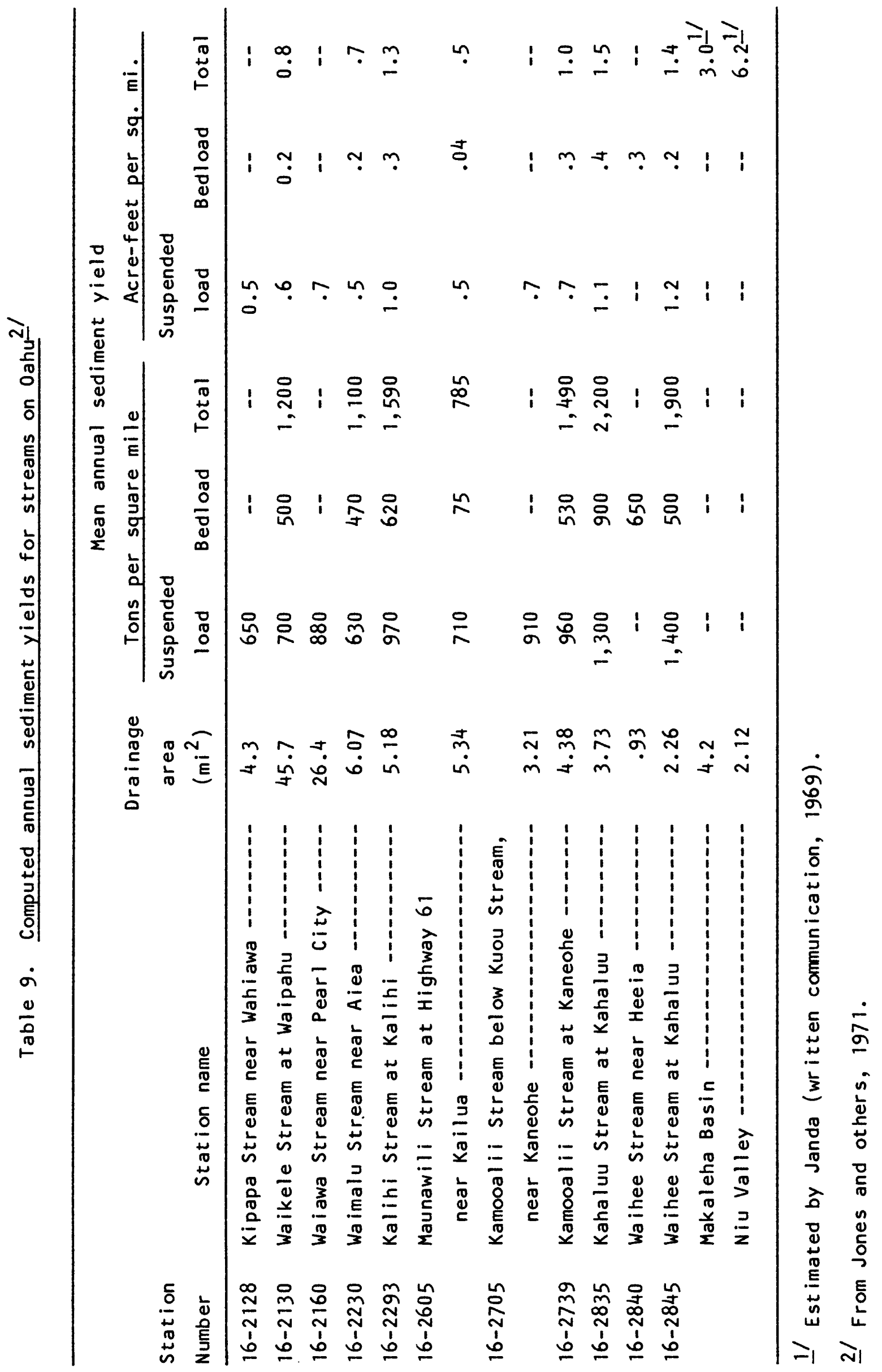




\section{CONCLUSION}

Reasonable values of mean annual suspended-sediment and total mean annual sediment yield for the Talofofo, Ylig, and Ugum River basins have been calculated by the flow-duration sediment-rating-curve and the PSIAC methods. The range of mean annual suspended-sediment yields established are $462-845$ tons $/ y r / \mathrm{mi}^{2}$ for the Talofofo basin, $977-1,162$ tons/yr/mi ${ }^{2}$ for the $\mathrm{Ylig}$ basin, and $855-1,455$ tons/yr/mi ${ }^{2}$ for the Ugum basin. The total mean annual sediment yields estimated are 1,200 tons/yr/mi ${ }^{2}$ for the Talofofo basin, 1,385 tons/yr/mi ${ }^{2}$ for the $\mathrm{Ylig}$ basin, and 1,210 tons/yr/mi ${ }^{2}$ for the Ugum basin. The values are supported by sedimentation data from Fena Reservoir and several similar basins on Oahu, Hawai i.

It appears from this study that the PSIAC method can be a useful tool in estimating sediment yields in some tropical areas. 


\section{REFERENCES}

Austin, Smith and Associates, Inc., 1968, A report covering the surface water survey of the island of Guam: Honolulu, Hawaii, 78 p.

Colby, B. R., 1956, Relationship of sediment discharge to streamflow: U.S. Geological Survey Open-File Report, $170 \mathrm{p}$.

Jones, B. L., Nakahara, R. H., and Chinn, S. S. W., 1971, Reconnaissance study of sediment transported by streams island of Oahu, U.S. Geological Survey Circular C33, 45 p.

Kennedy Engineers, 1974, Fena watershed and reservoir management study and plan: Unpublished processed report in files of U.S. Geological Survey, Honolulu, Hawa i , 139 p.

Miller, Carl R., 1951, Analysis of flow-duration sediment-rating curve method of computing sediment yield: U.S. Bureau of Reclamation, $55 \mathrm{p}$.

Pacific Southwest Inter-Agency Committee, 1968, Factors affecting sediment yield and measures for the reduction of erosion and sediment yield: Report of the Water Management Subcommittee, $13 \mathrm{p}$.

Park, M. E., 1978, Soil survey of Guam: Government of Guam, Department of Commerce, $243 \mathrm{p}$.

Shown, L. M., 1970, Evaluation of a method for estimating sediment yield, U.S. Geological Survey Professional Paper 700-B, 5 p.

Tracey, J. I. Jr., Stensland, C. H., Doan, D. B., May, H. G., Schlanger, S. 0., Stark, J. T., Blumenstock, D. I., Emery, K. 0., and Fosberg, F. R., 1959, Military geology of Guam, Mariana Islands. Part I, Description of terrain and environment. Part II, Engineering aspects of geology and soils: Headquarters U.S. Army Pacific, Office of the Engineer, 282 p.

Ward, P. E., Hoffard, S. H., and Davis, D. A., 1965, Hydrology of Guam, U.S. Geological Survey Professional Paper 403-H, 28 p. 